Portland State University

PDXScholar

6-3-2002

\title{
A Critical Review of Issues in Applying Restorative Justice Principles and Practices to Cases of Hate Crime
}

Terri Lee Kelly

Portland State University

Follow this and additional works at: https://pdxscholar.library.pdx.edu/open_access_etds

Part of the Criminology and Criminal Justice Commons

Let us know how access to this document benefits you.

\section{Recommended Citation}

Kelly, Terri Lee, "A Critical Review of Issues in Applying Restorative Justice Principles and Practices to Cases of Hate Crime" (2002). Dissertations and Theses. Paper 3629.

https://doi.org/10.15760/etd.5497

This Thesis is brought to you for free and open access. It has been accepted for inclusion in Dissertations and Theses by an authorized administrator of PDXScholar. Please contact us if we can make this document more accessible: pdxscholar@pdx.edu. 


\section{THESIS APPROVAL}

The abstract and thesis of Terri Lee Kelly for the Master of Science in Conflict Resolution were presented June 3, 2002, and accepted by the thesis committee and the department.

COMMITTEE APPROVALS:

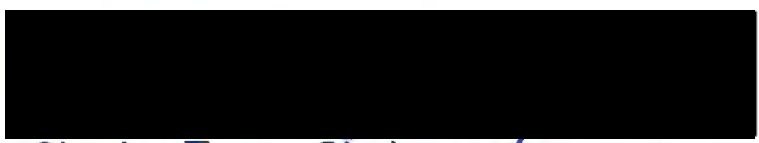

Charles Tracy, Chair 9

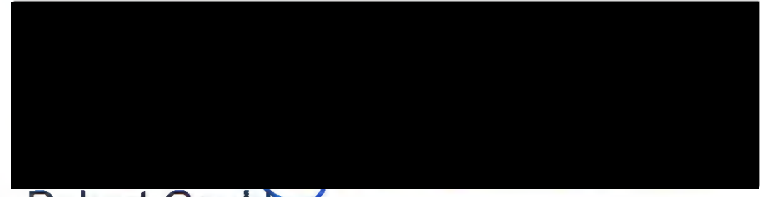

Robert Gould

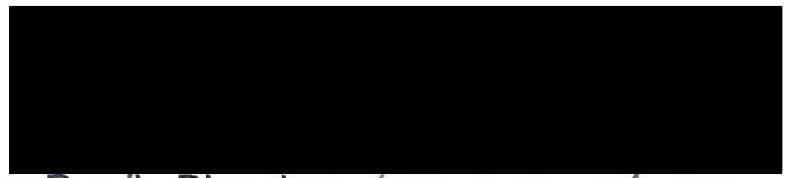

Randy Blazak

Representative of the Office of Graduate Studies

DEPARTMENT APPROVAL:

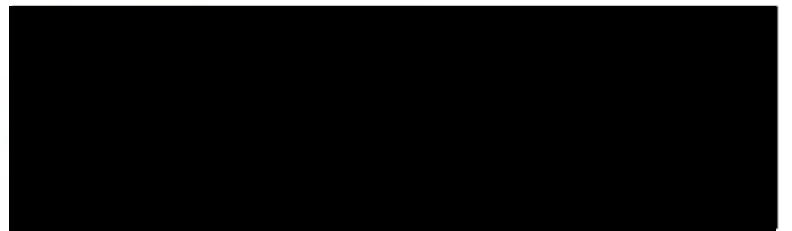

Robert Govld, Chair

Department of Philosophy 


\section{ABSTRACT}

An abstract of the thesis of Terri Lee Kelly for the Master of Science in Conflict Resolution presented June 3, 2002.

Title: A Critical Review of Issues in Applying Restorative Justice Principles and Practices to Cases of Hate Crime.

A restorative approach to justice focuses on accountability for healing the harm done to victims and communities as a result of criminal acts. Hate crimes are intended to send a threatening message to a particular group of people. There is enough reliable research on restorative justice principles and practices, and on the causes, meaning and impact of hate crimes, to bring together a representative selection of available literature for a critical review. This thesis critically reviews the literature of restorative justice principles and practices, and the literature of hate crime causes, definitions, laws, and typologies of offenders, using as a model Comstock's seven-step Critical Research Method. Findings suggest that congruencies between the two fields of study are primarily found in how activities appropriated to define the fields have increased the ambiguity of the definitions. Further findings suggest that there are important underlying issues of class and power distribution in need of attention in both fields of research. These findings are discussed and suggestions are made for future areas of research. 


\title{
A CRITICAL REVIEW OF ISSUES IN APPLYING \\ RESTORATIVE JUSTICE PRINCIPLES AND PRACTICES \\ TO CASES OF HATE CRIME
}

by

TERRI LEE KELLY

A thesis submitted in partial fulfillment of the requirements for the degree of

\author{
MASTER OF SCIENCE \\ in \\ CONFLICT RESOLUTION
}

Portland State University

2002 


\section{ACKNOWLEDGEMENTS}

This thesis would not have been possible without the kindness, patience, and careful attention extended to me by my thesis committee members: Dr.

Charles Tracy, my advisor; Dr. Robert Gould, and Dr. Randy Blazak. I would also like to acknowledge Dr. Barbara Guetti of the PSU English Department and Dr. Marilyn Peterson Armour at the University of Texas, for guidance and moral support. Finally, a big hug for my daughter, Autumn Dawley, who did more than her fair share of the household chores so that Mom could finish her thesis. Thank you all. 


\section{TABLE OF CONTENTS}

ACKNOWLEDGEMENTS

LIST OF TABLES

CHAPTER ONE

Introduction

CHAPTER TWO

A Brief History of Hate

CHAPTER THREE

A Brief History of Restorative Justice

CHAPTER FOUR

Methodology

CHAPTER FIVE

Causes of Hate

CHAPTER SIX

Definitions of Hate Crime

CHAPTER SEVEN

Hate Crime Law

CHAPTER EIGHT

Typologies of Hate Offenders

CHAPTER NINE

Restorative Justice Principles

CHAPTER TEN

Restorative Justice Practices

CHAPTER ELEVEN

Findings

CHAPTER TWELVE

Conclusion 


\section{LIST OF TABLES}

TABLE 1: Comstock's Steps in Research Methods 


\section{CHAPTER ONE}

\section{Introduction}

I did not heal by myself. I healed and continue to heal because people helped me. I got the best help I could imagine: emergency medical, police, legal, and personal. Not only my friends but also people who barely knew me and strangers who did not know me at all responded with warmth and also with outrage. It is only because of these responses that I have managed to heal. The only antidote to the horror of the shooting has been the incredible kindness that I have received since that time and the realization of the appropriate conclusion to the court proceedings (Brenner 184).

In May, 1988, Claudia Brenner and Rebecca Wight were making love by the side of a stream along the Appalachian Trail when they were shot eight times. A "mountain man," who the women had seen only once briefly along the trail, shot Claudia five times and Rebecca three times. Despite the five massive wounds on her face, neck and shoulders, Claudia managed to walk to a road and get help. She survived, but Rebecca died only a few minutes after the shooting began.

I read Claudia's account of the day her world "exploded" during the period of time that I was training to be a victim-offender mediator. Perhaps it was the synchronicity of reading about a hate crime that could have happened to me or any of my friends, and absorbing Claudia's words about how she healed, while at the same time learning how to bring meaning to face-to-face 
encounters between victims of crime and their offenders, that made me curious about just how effective restorative justice could be in cases of hate crime. Claudia said repeatedly in her book that much of her healing had to do with an abundant support system and from working towards making sure the shooter would "rot in prison" because "his life was worthless" (Brenner 185). At the time, I really wanted to believe that restorative justice could have a part in healing so great a harm. But I didn't know enough about the causes of hate crime to know definitively how effective it could be. And what Claudia Brenner had to say was challenging my training on how to balance the needs of both victims and offenders. There was also something bothering me about all the factors of the crime not discussed in her book -- who was the "mountain man" and what was going on in his world that made sense out of shooting lesbians? What is the nature of outrage? Why does it seem like there are deeper issues at work here - that people don't just wake up one day and decide to be murderous homophobes? It was these sorts of moments of feeling that there was something else going on, that compelled me to conduct research.

Brenner's book made it clear that horrible trauma has a deep impact on one's life, but that somehow it fosters soulful growth in a way that no other lifealtering event can. I wanted to know why Brenner ended up considering herself to be a stronger, more compassionate person after the long arduous process of healing form her ordeal. If restorative justice is to have a role in such a complex healing process, it will have to address the roles outrage and 
retribution play while healing. Could it be that restorative justice is helpful for only some types of crime, but not for hate crime? Certainly hate crime is a different variety of crime than robbery or vandalism--the sorts of crime I was used to dealing with in victim-offender mediation. But what made it different? Restorative justice is a way to focus on issues of accountability in a personal way. Who is accountable for hate crime - just the offender? Should the issue of hate even be brought up in a restorative justice action? Are mediators qualified to take it on? Is hate the only issue in a hate crime?

I read Eight Bullets (Brenner) in January 2001, and began reading for my thesis in February (though I had been reading material on both subjects hate crime and restorative justice - for some months beforehand). I thought it was going to take only a few months to read enough material to gain an understanding of where restorative justice could "fit" in the schema of hate crime. I was wrong. I'm still reading today, more than a year later, but I finally felt like I could begin writing a thesis a few months ago. Is there something about restorative justice principles and/or practices that can somehow contribute to an understanding of why people hate, or at least how to heal the harm done by hatred? I considered my job to be about separating the ominous questions into smaller, more manageable questions in order to find congruencies in the details. Some of those questions are: 
- What are the causes of hate?

- How do we define a hate crime?

- How do we define restorative justice?

- What do the laws say and who makes the laws?

- What does it mean to "do" restorative justice?

- Are there deeper issues at work?

These are a few of the many questions that came up for me as I conducted my research, but they were the most plausible candidates for finding an abundance of literature. I took the "sponge" approach to my research - I saturated my brain with literature until I could begin to see how some things went with other things, and other things I had assumed would go together actually did not. I also immersed myself in experiential learning, by participating in victim-offender mediation and also completing an intense training in "Severe Violence Dialogue" - the form of mediation that would be most appropriate for a case so described in Eight Bullets.

The thesis is arranged by chapters. The two chapters after this one are brief histories of the issues under study: hate crimes and restorative justice. The fourth chapter explains the methodology I used to unravel some of the complexity of these issues. The middle section of the thesis is comprised of the critical literature review - the heart of the thesis, because it is while accomplishing this review that I was able to see some of those "deeper 
issues" that made all the difference in the outcome. Then there is a chapter where I flesh out those deeper issues from the review -- where the congruencies and contradictions are revealed. The last chapter is a conclusion where I remember what I started out to do, and reflect on the journey.

There is so much to learn about both issues. I have only scratched the surface. I hope someone will go on from here, finding answers to some of the real tough questions this thesis brings up. 


\section{CHAPTER TWO}

\section{A Brief History of Hate}

Hate-motivated violence has been with us since the beginning of civilization. Violence organized around social characteristics and affiliation (or perceived affiliation) with a group is well-documented for atrocities such as the WWII Holocaust, the lynching of African-Americans in the U.S. (Bensinger; Kressel; Lutz; Newton and Newton), the more recent ethnic cleansing in the Balkans, and crimes spurred by the September 11, 2001, attack in the U.S. From 1882 to 1968 , nearly 5,000 African-Americans were lynched in the U.S. (Jacobs and Potter, Hate Crimes 60). Violence against gay men and lesbians in Western Europe over the last 400 years has been documented (Boswell; Katz). Historically, such violence was often present as official state policy, perpetrated by representatives of the state, as well as private citizens. The pervasiveness of religious, ethnic, and racial violence eventually led to the creation of metropolitan police departments (Friedman 105-107). In the early 1980s, activists demanded that U.S. lawmakers enact measures to control the escalation of hate-motivated intimidation and violence. As a result, a new category of crime emerged: the "hate crime" (Bensinger; Jacobs and Potter; Grattet and Jenness; Jenness and Grattet). 
The white supremacist movement is usually cited as a forerunner of all contemporary hate groups. The Ku Klux Klan, historically the most influential white supremacist organization in the U.S., was founded in 1865 , as a fraternal order for Civil War veterans of the confederate states. After a brief hiatus, the Klan reemerged in 1915, expanding its membership to between four and five million by 1925 (Blee, Women of the Klan 18). The American Nazi Party was founded in 1958 by George Lincoln Rockwell to honor the legacy of Adolph Hitler. The civil rights movements of the 1950s and 1960s triggered the next wave of interest in the Klan. Many contemporary neo-Nazi organizations are their direct descendants (Ferber; Blee, Racism).. There are a wide variety of white supremacy organizations today, including various Klan groups, skinheads, the neo-Nazi National Alliance, the National Socialist White People's Party, and the Posse Comitatus (Ferber). The white supremacist movement of the 1980 s gave birth to the militia movement, which has, in some corners, grown increasingly racist and anti-Semitic (Blee, Racism).

During the fist half of the 20th century, criminalization of hate speech, such as bigoted expressions or symbols, was popular among U.S. lawmakers. In Beauhamais v. Illinois (1952), the U.S. Supreme Court affirmed a state law that punished hate speech against racial, religious, or ethnic groups (B. Levin, Hate Crimes 10$).{ }^{1}$ However, the public criminalization of hate did not always mean that justice was done. In the early 1980s, two high school seniors in Washington D.C. were sentenced to perform community service rather than 
serve prison time after nearly beating to death a gay man (Herek and Berrill 280). In another case, Texas judge Jack Hampton excused his light sentencing of the murderer of two gay men by stating, "I put prostitutes and queers at the same level. . .and l'd be hard put to give somebody life for killing a prostitute." (294). In 1986, the Catholic Church denounced "violent malice in speech or in action" against gays, but then went on to blame such malice on the gay rights movement:

When civil legislation is introduced to protect behavior to which no one has any conceivable right, neither the Church nor society at large should be surprised when other distorted notions and practices gain ground and irrational and violent reactions increase."2

A city council member from Wilkes-Barre--a small city in Pennsylvania, near the site of the Wight/Brenner shootings--is quoted as saying that half of all gays should be shot and that AIDS is just what gay people deserve (295). A Broward County, Florida, Circuit Judge jokingly asks the prosecuting attorney in a 1988 case involving the beating death of an Asian-American gay man, "That's a crime now, to beat up a homosexual?" (295).

These are examples of incidents that led researchers to begin documenting, as an academic discipline, the history of hate crime and its impact on all levels of society.

Some of the most recent research conducted on the issue of hate crime has emphasized the impact on victims. Research by The Prejudice Institute 
(Ehrlich et al) found that the targets of criminal and non-criminal bias attacks experienced $21 \%$ more adverse psychological and physiological symptoms than those who faced similar conduct that was not bias related (65). Another study by the same group found that "many victims fear for their safety and for their family's safety ... many of them report changes in their lifestyle - where they walk, how they answer the phone, and [that] the ... fear can totally disrupt their lives" (63). A more recent study concluded that hate crime victims suffered heightened and more prolonged bouts of "depression, stress, and anger than victims" of non-hate crimes. The report further concluded that hate crime victims "continued to have symptoms for as long as five years after their victimization," while crime-related psychological symptoms declined significantly among victims of non-bias crimes within two years of the incident (APA).

The effects of hate crimes reverberate beyond individual victims, causing measurable injury to the community at large. Public injury is a traditional justification for punishing crime (B. Levin, Hate Crimes 18). ${ }^{3}$ The two most serious threats to the public resulting from hate crimes is a heightened tension between groups that are already hyper-vigilant, and an increased risk of civil disorder. These threats are more pronounced with hate crimes than with non-hate crimes (19). Hate crimes also may spur retaliatory violence (20). After the racially-motivated murder of an African-American man in Howard Beach, Queens, in 1986, the New York City Police Department 
documented more hate crimes in the month that followed than in the previous three months combined (10).

Most recently the public has felt the effects of the dragging murder of James Byrd by admittedly racist assailants in Jasper, Texas, and the brutal murder of Matthew Shepherd, a gay Wyoming college student who was tied to a wooden fencepost, beaten, and left to die. These crimes stand out as national tragedies, rather than just horrible local events. Each atrocity not only shocks the country, it sends out a threat to all racial, ethnic, or sexual minorities that, even today, they are at a special risk for horrible violence and death, no matter where they are or what they are doing.

Notes

1 Although never technically overturned, subsequent Supreme Court decisions have clearly rejected all the foundational arguments of the case, and it is no longer regarded as sound law. Levin cites as evidence Texas $v$. Johnson, 1989 (offensiveness is insufficient basis to punish speech), and Smith v. Collin, 1978 (Supreme Court refuses to deny order of Court of Appeals allowing a Nazi march).

2 Vatican Statement, "Congregation for the Doctrine of the Faith" (1986).

${ }^{3}$ Levin cites Coker v. Georgia (1977), when the Supreme Court found the death penalty unconstitutional for the crime of rape, citing racial discrimination. 


\section{CHAPTER THREE}

\section{A Brief History of Justice}

Accounts of conceptions of restorative justice claim roots in both

Western and non-Western traditions. Some advocates claim restorative justice has been the dominant model of criminal justice throughout most of human history for all the worlds' people (Galaway and Hudson 1; Braithwaite, Crime; Strong and Van Ness; Zehr, Lenses). A move towards a restorative model of justice is often interpreted as "a return to the roots of justice" (Davis 1-2;

Llewellyn and Howse). ${ }^{1}$ The dominant approach to justice has been described as "community and victim-centered justice" in aboriginal cultures and in early civilizations (Bianchi). For example, one traditional Navajo justice ceremony is called Hozhooji Naat'aanii. The term refers to talking and planning to restore damaged relationships, guided by a wise elder. This is referred to as "Justice and Harmony Ceremony," or a healing ceremony incorporating rituals of prayer, self-expression, dialogue, reconciliation, and consensus (Yazzi 10).

In late 11th century Europe, new laws were studied by scholars in the Catholic Church and disseminated throughout the Western world. The Church dealt harshly with its religious heretics, and so the secular states began to follow the lead by calling its social heretics "criminals" and meting out 
punishment accordingly. "Victims" were no longer considered the actual individual victims -- crimes came to be recognized as inflicted upon the King and Queen themselves, which eventually evolved into "crimes against The State" (Haley 9). The state began, as a criminologist said provocatively this century, to "steal the criminal conflict from the community" (Christie, Limits 93). In the U.S., it is still a shock for some victims to discover that they are not even named in court, having been displaced by the ambiguous "We the People" as written in the U.S. Constitution (Haley 10). The purpose of the law also shifted. Earlier, the emphasis had been upon making the victim whole again, what in the ancient Hebrew culture was called "restoring shalom." Later, the purpose became to uphold the authority of the state (12). There evolved a dominant Western religious emphasis upon the offender's violation of the law, which eventually overshadowed concern for the victim. It also drew on Roman slave law as a model for punishing the offender. This form of response to crime is now regarded as "retributive justice" and has dominated Western jurisprudence for a millennium (18).

The Quakers tried in 1790, in Philadelphia, Pennsylvania, to move away from the retributive model towards an emphasis upon reforming the criminal. They thought the offender might become "penitent" if they were each locked up by themselves for years with only a bible for company (Foucault 28). The new name for this form of response to crime was the penitentiary (29). 
The new motive was rehabilitation, not retribution. The idea caught on and spread, but an unfortunate side effect began to arise: the dreadful loneliness and silence drove offenders stark-raving mad. The penitentiary destroyed the very psyche of the convicted criminal (35).

Restorative justice is a distinctively different model from any retributive or rehabilitative approach that treats people not as social beings but as objects to manipulate (Walgrave 230). Since the 1970s, as dissatisfaction with the traditional justice system mounted regarding its handling of crime, restorative justice emerged as an alternative process for addressing the impact of crime on both victims and offenders. Until that time, there was general concern that victims' needs were too often compromised by an impersonal judicial system that still focused on procedures over people. When victims were required to attend court, they were often made to feel that they were there only as evidence for the case against the defendant(s). Meanwhile, offenders were placed in a passive role while the professionals (lawyers, judges, investigators) took control of the conflict and directed the process of measuring justice and retribution.

Then in 1974, two youths who had been drinking and who had already had run-ins with police, took out their frustrations on the small community of Elmira, Ontario, Canada, by vandalizing 22 vehicles and homes. Several months later the youths pleaded guilty to the charges. Probation Officer Mark 
Yantzi, probably influenced by several discussions he'd had with local Mennonite peacemakers regarding the need for judicial reforms, proposed in his Pre-Sentence Report that the youths would benefit from meeting face-toface with their victims and making amends. The Judge saw merit in the proposal, and made a fateful choice to put off sentencing until Yantzi and Mennonite volunteer Dave Worth could take the youths to meet each of the victims. They did, and out of that experience arose the first ever "victim offender reconciliation project" (Peachey).

It was an American psychologist, Albert Eglash, in 1975, who first used the term restorative justice to describe various processes of informal justice in existence at that time, such as the Elmira Case. Eglash identified three types of criminal justice: retributive justice based on punishment; distributive justice based on therapeutic treatment of offenders; and restorative justice based on the overall impact of the crime (43). Restorative justice focuses on the harmful effects of offenders' actions and actively involves victims and offenders in the process (53). From this premise arose a number of American and Canadian Victim-Offender Reconciliation Programs (VORPs). These programs bring victims and offenders together to meet with a mediator and talk with each other. Both sides had an opportunity to express their experience, thoughts and feelings. The parties can also negotiate their own way to "make things right." (Zehr, VORPs 4). 
This history briefly summarizes the evolution of the criminal justice system in the West away from community and victim-centered justice and towards state and offender-centered justice. Other efforts apart from what was generally known as "restorative justice" have nevertheless recently become included in the generalization of the term. Efforts for public reparations and apologies for wide-scale atrocities also focus on healing the harm done. "Truth \& Reconciliation Commissions" investigate crimes against humanity, compensate victims, issue reparations and try to reconcile divided peoples after large scale genocidal atrocities. South Africa, which created its first Truth and Reconciliation Commission after apartheid, hoped that confronting murder and torture would somehow help to heal the harm done on a mass scale (Yamamoto, von Truensee). These commissions are a step toward addressing harms done across cultures and liberating the future from the past. Argentina convened a truth commission in 1983, followed by Uruguay, Chad, Chile, EI Salvador, Chile and Germany. The value of truth commissions is gaining recognition due to the increased global focus on human rights (von Struensee).

The Vatican's long awaited Holocaust document calling for repentance for those who had not acknowledged the evil of Jewish genocide, as well President Clinton's African apology for the American participation in the slave trade, and other efforts to mediate conflicts are all part of a growing interest in 
reconciliation and forgiveness in the context of political and interpersonal violence (Hohri 25). Yet, refusal and denial by political leaders as well as private citizens to be truthful about past events, on intrapersonal, interpersonal, national and global levels is still pervasive (26).

Notes

${ }^{1}$ Recent criticism argues that this claim as fact is baseless. See Kathleen Daly, "Restorative Justice: the real story," Punishment \& Society 4.1 (2002): 55-79. 


\section{CHAPTER FOUR}

\section{Methodology}

Exploratory research is conducted into an issue or problem where there are few or no earlier studies to refer to. That certainly goes for this review, as there appears to be little or no documented connection between restorative justice theory and hate crimes research. Therefore, this review is necessarily qualitative, due to its inductive, prescriptive, and exploratory nature. Bogdan and Biklen described qualitative methods as:

"...an umbrella term to refer to several research strategies that share certain characteristics. The data collected have been termed soft, that is, rich in description of people, places and conversations, and not easily handled by statistical procedures. Research questions are not framed by operationalizing variables; rather, they are formulated to investigate topics in all their complexity, in context." (2)

Marshall and Rossman suggest the link between qualitative and exploratory methods, particularly in cases where the phenomenon "unfolds at the time of the study" (17). McClure and Lopata further argue for a strong link between exploratory research and qualitative methods:

"Qualitative techniques are especially appropriate for use in situations where the research problem and the research setting are not well understood... When it is not clear what questions should be asked or what should be measured, a qualitative approach will be more useful." (11) 
Since my review explores issues that are both "not well understood" and that are "unfolding at the time of the study," an exploratory focus is appropriate. One approach is to perform a critical review of literature for the purpose of developing new conceptual frameworks within which any given class of values may be more faithfully and fully represented (Wicker 1094). Wicker proposes four strategies for expanding conceptual frameworks:

(1) play with ideas

(2) consider contexts

(3) tinker with assumptions

(4) clarify and systematize the conceptual framework (1095).

New frameworks can also emerge by integrating and combining existing frameworks in revealing ways. A good example would be recent efforts to combine the frameworks of economics and psychology to better understand green values (Peterson et al). Frameworks are not necessarily unbiased. Frameworks can implicitly or explicitly assume a set of values. It may even be that the intention for the emerging framework is to emphasize and foster a particular set of values (Wicker 1101). Exposure to a wider range of frameworks will help researchers better understand the frameworks and perspectives that others might bring to the table. From such shared 
understandings may come some new frameworks capable of embracing a wider range of perspectives and values.

Conceptual frameworks help to organize and structure the process of defining problems, gathering information, identifying and evaluating alternatives, and making decisions. It is the intention of this review to reveal values important to the evolution of a conceptual framework that would include restorative justice in a resolution for hate crimes. Toward that goal, this review follows Comstock's model of inquiry in order to assist in the development of a progressive framework for future researchers of restorative justice and hate crimes.

Comstock's model differs from that of the more traditional Positive Social Science method in subtle but significant ways (see Table 1). The aim of this method is to continually broaden and deepen the participants' awareness of the meaning and probable outcome of a course of action:

The aim is the subjects' progressive movement toward an understanding of the totality of historical circumstances that affect them.... Its aim is enlightened self-knowledge and effective political action. Its method is dialogue, and its effect is to heighten its subjects' self-awareness of their collective potential as the active agents of history (Comstock, Red Feather).

Critical research of this sort links social processes to its subjects' choices and actions with the goal of eliminating unrecognized and contradictory consequences of collective action. ${ }^{1}$ 
Table 1. Steps in Research Methods of Positive \& Critical Social Sciences (Comstock)

\begin{tabular}{|c|c|}
\hline Positive Social Science & Critical Social Science \\
\hline $\begin{array}{l}\text { 1. Identify a scientific problem by studying the } \\
\text { results of past empirical and theoretical work. }\end{array}$ & $\begin{array}{l}\text { 1. Identify social groups or movements } \\
\text { whose interests are progressive. }\end{array}$ \\
\hline $\begin{array}{l}\text { 2. Develop empirically testable hypotheses } \\
\text { which promise to improve the theory1s } \\
\text { explanatory and predictive power. }\end{array}$ & $\begin{array}{l}\text { 2. Develop an interpretive understanding } \\
\text { of the intersubjective meanings, values, } \\
\text { and motives held by all groups in the } \\
\text { setting. }\end{array}$ \\
\hline $\begin{array}{l}\text { 3. Select a setting (community, group, } \\
\text { organization, etc.) which is suitable to the } \\
\text { scientific problem. }\end{array}$ & $\begin{array}{l}\text { 3. Study the historical development of the } \\
\text { social conditions and the current social } \\
\text { structures that constrain actions and } \\
\text { shape understandings. }\end{array}$ \\
\hline $\begin{array}{l}\text { 4. Develop measures and data-gathering } \\
\text { strategies based on: } \\
\text { Previous research } \\
\text { Observations and interviews in the setting } \\
\text { The investigator's own "common-sense" } \\
\text { Knowledge of social processes }\end{array}$ & $\begin{array}{l}\text { 4. Construct models of the relations } \\
\text { between social conditions, intersubjective } \\
\text { interpretations of those conditions, and } \\
\text { participants' actions }\end{array}$ \\
\hline $\begin{array}{l}\text { 5. Gather data through: } \\
\text { Experiments } \\
\text { Existing documents and texts } \\
\text { Surveys and interviews } \\
\text { Observations }\end{array}$ & $\begin{array}{l}\text { 5. Elucidate the fundamental } \\
\text { contradictions which are developing as a } \\
\text { result of actions based on ideologically } \\
\text { frozen understandings. } \\
\text { Compare conditions with understandings } \\
\text { Critique the ideology } \\
\text { Discover immanent possibilities for action }\end{array}$ \\
\hline $\begin{array}{l}\text { 6. Analyze data to test the truth value of these } \\
\text { hypotheses. } \\
\text { Discard all those hypotheses which do not } \\
\text { reach } .05 \text { degree of probability. }\end{array}$ & $\begin{array}{l}\text { 6. Participate in a program of education } \\
\text { with the subjects that gives them new } \\
\text { ways of seeing their situation. }\end{array}$ \\
\hline $\begin{array}{l}\text { 7. Aiter social laws and social theory in light of } \\
\text { findings and restate scientific problem to be } \\
\text { addressed by subsequent research. }\end{array}$ & $\begin{array}{l}\text { 7. Participate in a theoretically grounded } \\
\text { program of action which will change social } \\
\text { conditions and will also engender new, } \\
\text { less alienated, understandings and needs. }\end{array}$ \\
\hline
\end{tabular}


My research began with a broad reading of the literature on hate crimes and on restorative justice for more than a year. I also read material regarding victim and offender experiences. Then I selected a range of articles and books that appeared to best represent the material I found in the broader examination, on the basis that they were the most often cited. I organized this selection into sections for a critical literature review, and noted congruencies of principles, goals, and standards as I reviewed. I followed Comstock's seven-step critical research method (Table 1, 2nd column) inductively, to integrate congruencies holistically into a shared set of considerations for any future framework that would bring restorative justice principles and practices to the social problem of hate-motivated violence. The result is an holistic narrative framework for the benefit of future research.

In my thesis chapters that outline the histories of restorative justice and hate crimes, I aimed to fulfill Comstock's steps one and three. In the literature review, I aimed to fulfill steps two and four. In the chapter on "Findings" I aimed to fulfill steps five and six. In the conclusion, I aimed for step seven. Individual methodological concerns that arose in the critical literature review are detailed in the introductory segments of each review section.

Notes

${ }^{1}$ Comstock often cites Ake Sandberg, The Limits to Democratic Planning. Stockholm: Liber Förlag, 1976, as a basis for his model. 


\section{CHAPTER FIVE}

\section{Causes of Hate}

Research on causes of hate crimes often refers to literature about the function and nature of prejudice itself, since a hate crime can be said to be the result of what lies at the extreme end of a scale that has at the other end a benign basic human propensity to play favorites. Jack Levin has written a seminal work about this subject and is often cited. In his book The Functions of Prejudice, Levin explains that prejudice is a learned part of human nature and serves important psychological functions. A working definition of prejudice from a psychological view is "a negative attitude toward the members of a minority group" (13). ${ }^{1}$ Prejudices serve individual psychological functions such as displacing aggression, protecting self-esteem, reducing uncertainty, and positive social functions such as the maintenance of occupational status, the performance of unpleasant or low-paying jobs, and the maintenance of power structures (36). Overall, prejudice serves to maintain solidarity, and reduce competition and uncertainty in a given society (36).

Another oft-cited work regarding the causes of prejudice is The Nature of Prejudice. In his book, the late Harvard psychologist Gordon Allport analyzed prejudice to find out something about its nature by studying its 
interpersonal and societal dynamics. One interesting finding that has relevance for this thesis is there are two kinds of prejudice - hate-prejudice and love-prejudice. With hate-prejudice, the hater wants the object of his hate eliminated. Love-prejudice is "the tendency to over-generalize our categories of attachment and affection" (25) such as when a person argues for affirming their way of life, or by stating they are pro-white, not anti-black. It is a way to defend one's position, privileges, and self-interest. They do not necessarily want to actively eliminate the object of their prejudice, they simply do not acknowledge their status as having any relevance to their own group.

Allport argues that a majority of people have contrary impulses about their own prejudices. On one hand, they recognize they have prejudices and are likely to defend them, and on the other hand, they recognize that prejudices are morally distasteful and they are ashamed of them. Then Allport looks at how people handle these contrary impulses and finds that "psychologically speaking, there seems to be four modes" (334) of how the conflict is handled.

1) Repression (denial). "We don't have a racism problem in our town..." "I am not prejudiced but..." Sometimes it's because people think there's no problem as long as there is no overt violence. What they're really saying is "We don't have a riot problem here." Or they may be so used to collectively reinforced 
prejudices that they regard them as normal. Also, to deny that a problem exists is to put off the turmoil that will be caused by facing the problem (334).

2) Defensive Rationalizations. "The most obvious way to preserve one's prejudices, and keep them from conflicting with ethical values, is to cite 'evidence' in their favor. This 'evidence' is made stronger through selective perception and selective forgetting, and by giving an "impression of universality" leading to assertions such as one made by a student in Allport's study: "There seems to be a unanimous feeling against the Jews, not only in this country, but throughout the world" (335).

3) Compromise Solutions. An unfortunate fact of social life is that the many roles a man has to play in his life compels him into inconsistent behavior. We are not only permitted to contradict ourselves but are encouraged to do sodepending on the situation. A white shop owner in the South may feel compelled by his social role and status in the neighborhood not to hire blacks in his store, but he also is compelled by the same forces to donate generously to the building of a black hospital. "We cannot say that such inconsistency in behavior is abnormal. Indeed, it is the rigid consistency of the fanatic (whether of a bigot or a crusader for equal rights) that is regarded as pathological in our society" (337). ${ }^{2}$ One of the most common ways of handling the inner conflict caused by these inconsistencies is to alternate between prejudices and 
ethics. Since most people have both prejudiced attitudes and a personal values system, they avoid being overwhelmed by the conflict by expressing one or the other at various times depending on the situation.

For example, in a report by John B. Stevens, Jr., prosecutor in the trials of two of the men who were handed the death penalty for the bias-motivated murder of James Byrd in Jasper, Texas, Stevens notes how the people of Jasper don't consider their town to be a racist town - there are backs on the city council and school board and they have a black mayor. However, "it did not go unnoticed by members of the press that a cemetery in Jasper had a fence which separated the graves of whites and blacks." ${ }^{3}$

Most influential in our decisions of which value system to use is the fact that we are compelled to play multiple roles in our lives. The pressure on us to conform in contradictory ways is great. In certain situations we are one thing, in other situations, something else. "To be a conformist under diverse sets of conditions is almost unavoidably to compromise one's integrity as a person" (Allport 338).

4) Integration. There are those who consider this inconsistency of their role behavior as a threat to their integrity. The inconsistencies should not be so critical that they splinter one's basic value system. Those who want integration wish to face their prejudices and ethics and put them all "under the dominance of a wholly consistent philosophy of human relationships" (338). This striving 
for wholeness and maturity requires a consistency that is extremely hard to achieve (338). ${ }^{4}$ They accomplish this by first discriminating between "fanciful sources of evil (prejudice) and genuine sources" (338). The delusions of scapegoats who have nothing to do with one's troubles disappear in an integrated personality. Resentments and hatreds are then directed strictly at those who actually threaten basic value systems (339).

To put the matter another way, we may say that anger is an emotion, whereas hatred must be classified as a sentiment --an enduring organization of aggressive impulses toward a person or toward a class of persons. Since it is composed of habitual bitter feeling and accusatory thought, it constitutes a stubborn structure in the mentalemotional life of the individual. And since it makes for social disruption, and is condemned by religion, it has a strong ethical tinge, though the hater usually manages to avoid conflict about the matter. By its very nature hatred is extro-punitive, which means that the hater is sure that the fault lies in the object of his hate. So long as he believes this he will not feel guilty for his uncharitable state of mind [italics mine] (363).

How do these basic human prejudices progress to the explosion of hate crimes at the extreme end of the scale? In his essay, entitled appropriately "Causes of Prejudice," Aronson summarizes four themes of theories of causes: (1) economic and political competition or conflict, (2) displaced aggression, (3) personality needs, and (4) conformity to existing social norms (Aronson 128). According to the first theory, if there are limited resources, the dominant group may exploit a minority group in order to gain an economic and/or political advantage (128). Prejudice then carries more weight when balanced against one's basic values, since survival is a basic value. This has 
been a popular basis for social engineering programs since the 1960 s.

However, there is reason to believe that it doesn't wash in practice.

An experiment was carried out by Muzafer Sherif ${ }^{5}$ and his colleagues to test this theory. Sherif randomly assigned 12-year-old boys to two groups at a Boy Scout camp. Within each group the boys were taught to cooperate. After they were all getting along well and peaceably with members of their particular group, Sherif set up a series of competitive activities to pit each group against each other, with prizes awarded to the winning group. There were also situations set up to disrupt the balance of fairness in the distribution of food. As predicted, these conflicts and disruptions resulted in name-calling and food-throwing between members of each group, "and within a very short time a full-scale riot was in progress" (Aronson qtd. in Baird 131). Then Sherif eliminated the staged conflicts and initiated non-competitive social contact between the boys. But to the surprise of all, this did not end the hostilities...in fact, hostilities escalated, even when the boys were engaged in benign activities like sitting around watching TV. (131) Sherif did eventually succeed at reducing the hostilities. Exactly how will be discussed later in this thesis.

Sociologist Randy Blazak attributes the rise in skinhead activity in the late 1980 s and early 1990 s in part to forces of economics, but with additional criteria that contributes to the political side of this cause. In Blazak's 1995 ethnographic study of skinheads he found that the rise is also influenced by "[t]he patriarchal reaction" or "the new power of women and homosexuals 
[threatening] many men who clung to traditional definitions of masculinity" (Wooden \& Blazak 151, Blazak Ethnographic study).

The scapegoat theory of prejudice makes the point that aggression is caused by a multi-faceted glob of frustration, pain, and boredom that, together, is "too big or too vague for direct retaliation." (Aronson 132) This unpleasant glob took a long time to form, which increases the probability that the globee will take it out on a less powerful member of society. The unpleasantness may even have been in part caused by aggression directed at the globee by members of the less powerful group who will now become the target. It may prove impossible for the frustrated individual to return the aggression to the very same person or people who hurt him/her, so the most available target is any member of the same group. This theory makes a little more sense than the competition theory when considering reasons behind the lynching of blacks or the Holocaust---situations which don't easily reduce down to strictly a matter of economics.

The prejudiced personality theory is a natural extension of the scapegoat theory, in that it explains why there are some frustrated people who will decide to commit hate crimes against the scapegoat, and some who will not. The difference is a predisposition to traverse to the extreme end of the scale. These personalities tend to be authoritarian, rigid in their beliefs, intolerant of weakness, and highly punitive, among other identifying characteristics (134). 
Finally, the conformity theory arises from anomalies in what would expected to occur based on the other theories. For example, it was found that, in 1942, 56 percent of all northerners and only 4 percent of all southerners were in favor of desegregation, at a time when northerners were experiencing more economic competition and southerners experiencing less. (136) In addition, although there is more prejudice against blacks in the South, there is less prejudice against Jews in the South than there is in the nation as a whole (136). So, these and other similar anomalies through the years are not congruent with economic or scapegoat theories.

Thomas Pettigrew suggests that the reason for these anomalies is conformity. ${ }^{6}$ People are simply conforming to the norms that exist in their society. "The historical events of the South set the stage for greater prejudice against blacks, but it is conformity that keeps it going" (Aronson 136). A study of interracial tension in South Africa ${ }^{7}$ showed that those who were most likely to conform to a variety of social norms were also more likely to show a higher degree of prejudice (137). Hatred and prejudice may be sparked by economic hardship, frustration, displacement, or personality disorder, but the wind that fans the flames into an explosion of hate crime is the pressure to conform.

Blazak offers another critical theory that incorporates most of the themes above, but that also focuses on how all these pressures work together to put potential hate crime offenders into a state of "normlessness." (Blazak, White Boys 986): 
Existing as a sense of "normlessness" or as a disjunction between aspirations and expectations, this state is reflected in a form of psychological distress or strain. Whether it is Agnew's (1992) general strain theory or Messner and Rosenfeld's (1994) institutional anomie theory, the human face of strain is the same: frustration, anger, and a need to resolve some perceived inequity (986). ${ }^{8}$

Finn and McNeil agree that economic competition by minorities is an aggravating factor in some attacks, which may be a partial explanation of the vandalism and arson directed toward the seemingly unrelated Korean-owned businesses during the 1992 post-Rodney King verdict rioting in Los Angeles. Howard J. Ehrlich further expounds "..that three basic threats evoke a violent response: violations of territory or property, violations of the sacred, and violations of status...the victim's behavior or potential behavior is defined by the actor as leaving no choice but to respond with violence" (Ehrlich qtd. in Herek and Berrill 108-109). The victims may "perceive their offenders as representative of the dominant culture in society and an agent of that culture's stereotyping of the victim's culture" (Young 19).

Finally, a recent study by Carolyn Petrosino found five distinct causes of hate crime based on a comparative analysis of historical data dating back to 17th century America (Petrosino). "The distillation of conditions surrounding hate crime dynamics both past and present, along with the examination of current trends suggest the following summary factors: 
(a) racism is a primary predictor of hate crime through time; (b) the efficiency and degree of harm potential in hate crime is a function of opportunity and technology; (c) hate crimes will occur more frequently and be more difficult to prevent; (d) notwithstanding the repugnant nature of hate crime, many Americans are becoming more sympathetic to the hate crime perpetrator's cause; and (e) hate crime, on some levels, is becoming indistinguishable from domestic terrorism" (abstract).

These findings demonstrate the urgency needed to find solutions to the problem of hate crime in the United States.

Notes

${ }^{1}$ Also see Howard J. Ehrlich's The Social Psychology of Prejudice (New York: Wiley, 1973); and Bernard M. Kramer's "Dimensions of Prejudice," The Journal of Psychology 27 (1949): $389-451$.

2 Italics mine. The similarities in the definitions of a fanatic and the "integrated" individual who has overcome their prejudices will be discussed in my findings.

${ }^{3}$ This is from an unpublished report handed out to conference attendees at the Oregon Hate Crimes Conference in Eugene, Oregon in February, 2001. It is entitled "Hate Crimes" by John B. Stevens, Assistant United States Attorney for the Eastern District of Texas. He was the chief federal prosecutor in the 1998 trials of two of the men who were handed the death penalty for their major roles in Byrd's bias-motivated murder. Stevens also notes that after the trial, the cemetery fence was taken down.

4 Italics mine. The similarities in the definitions of a fanatic and the "integrated" individual who has overcome their prejudices will be discussed in my findings.

${ }^{5}$ Aronson refers to M. Sherif, O.J. Harvey, B.J. White, W. Hood, and C. Sherif. Intergroup Conflict and Cooperation: The Robbers Cave Experiment. Norman: University of Oklahoma Institute of Intergroup Relations, 1961.

${ }^{6}$ Aronson cites T.F. Pettigrew. "Regional Differences in Anti-Negro Prejudice." Journal of Abnormal and Social Psychology 59 (1959): 28-36.

${ }^{7}$ Aronson cites Pettigrew, "Personality and Sociocultural Factors and Intergroup Attitudes: A Cross-national Comparison." Journal of Conflict Resolution 2 (1958): 29-42.

${ }^{8}$ Blazak cites Agnew, R. "Foundations for a general strain theory of crime and delinquency." Criminology 30, 1992:47-87; and Messner, S. F., \& Rosenfeld, R. Crime and the American dream. Belmont, CA: Wadsworth, 1994. 


\section{CHAPTER SIX}

Defining Hate Crimes

At least two seminal works which referred to most of the books and articles I read qualify, in my opinion, as indispensable resources for deconstructing the issue of defining hate crimes. Even though many works tackle this issue, I have pulled much of my material for this review from The Future of Terrorism: Violence in the New Millennium, (1998, Ed. Harvey W. Kushner, Thousand Oaks, CA: Sage Publications), and Hate Crimes: Criminal Law \& Identity Politics by James B. Jacobs and Kimberly Potter (1998, New York: Oxford). I found these two books to be good examples of representing a variety of views on the problem of defining "hate crime." I have also included a few other works that I sought for further comment after reading about them in one of these two books or finding them on my own.

Part of the problem facing hate crime researchers is defining exactly what is a hate crime. Proponents have labeled everything from bigoted speech to political disagreements to disparagement of agricultural products as hate crimes (B. Levin Hate Crimes).

In defining "hate crime," one hate crime detective told me that though he was not able to clearly define the term, "I know it when I see it." In this fashion, the meaning of "hate crime" depends largely on what is not a hate 
crime. The controversial issues surrounding the defining of hate crimes has something in common with the equally controversial issues surrounding the defining of domestic terrorism. "Unlike other areas of criminology that have a precise definition of the criminal event (e.g., aggravated assault, robbery, murder, drug trafficking), there is no social scientific consensus on the meaning of domestic terrorism. " (Hamm, Future of Terrorism 61). Likewise, hate crime is alternatively defined as right-wing violence, ${ }^{1}$ xenophobic violence, ${ }^{2}$ racist violence, ${ }^{3}$ racial attack or racial harassment, (Bowling qtd. in Hamm Conceptualizing Hate Crime 1-3) and racial violence (Bowling qtd. 3; Witte qtd. 92). Some do not consider "the symbolic status of victims or the motivation of perpetrators and simply treat the problem with existing criminal statutes" (Hamm, Future of Terrorism 68).

Crimes motivated by hate or bias against minorities have been called hate crimes, hate-motivated crimes, bias crimes, bias-motivated crimes, posssible bias crimes, and ethnoviolence (Hamm, Conceptualizing Hate $\underline{\text { Crime) }}$. Such attacks have also been officially classified as acts of domestic terrorism" (Hamm, Future of Terrorism 68). Regardless of the attacker's motives, victims almost always are chosen for what they are rather than who they are. "This is why anti-gay hate crimes are a form of terrorism. The attack is against the community as a whole" (Herek and Berrill 58).

The U.S. Federal Bureau of Investigation (FBI) uses the following definition: 
A hate crime, also known as a bias crime, is a criminal offense committed against a person, property, or society which is motivated, in whole or in part, by the offender's bias against a race, religion, disability, sexual orientation, or ethnicity/national origin.(UCR).

According to the F.B.I. definition, bias crimes are therefore not separate offenses, but acknowledge a specific motivation for a criminal event. This motivation is considered more pernicious and disruptive to communities, imposing "..distinct emotional harm on victims" (Levin and McDevitt 10). In 1993, 23 states used the FBI definition of hate crime ${ }^{4}$ (Hamm, Future of Terrorism 69), but states have been revisiting and enhancing these definitions ever since. For example, Oregon's hate crime definition currently includes harm done to victims because of "perceived race, color, religion, national origin, sexual orientation, marital status, political affiliation or beliefs, membership or activity in or on behalf of a labor organization or against a labor organization, physical or mental handicap, age, economic or social status or citizenship" (Perry 8). Some states are currentiy reviewing the legality of including under the hate crime definition historical acts such as the slave trade in early America and the forcible removal of Native Americans from their lands as officially-sanctioned programs. These are all representative examples of how extensive the definition can become:

Therein lies the dilemma of defining hate crime. As with 'crime' in general, it is difficult to construct an exhaustive definition of the term. Crime -- hate crime included-- is relative. It is historically and culturally contingent. As the example[s] suggest, what we take as hate crime today ... in another time, in another place, may be standard operating procedure (8). 
William Ellis argued before the National Research Council, "bias crime is a form of political violence" (Ellis 2). State governments and local municipalities have further muddied the waters by creating their own definitions in accordance with local traditions:

Along with "religion, race, ethnicity, or sexual orientation," some states identified additional victim categories. Connecticut, for example, added those with "physical disabilities" to the list of possible victims. Florida added "color and ancestry" to the list, but not physical disability. Illinois added "color, creed, ancestry, and physical or mental disability." Rhode Island included the general categories of "disability" and "gender," but left out color, creed, and ancestry. And although Pennsylvania adopted most of the FBl's definition, the state did not recognize sexual orientation as a victim classification. It is possible, then, for the states to accept in full the FBl's definition of hate crime, to add victim classifications, or to delete those parts of the definition they may find inconsistent with local traditions. (Hamm, Future of Terrorism 70)

The states can also identify specific offenses. In 1998, thirty-one states recognize cross burning as a hate crime. Twenty states did not have crossburning as a separate category (apart from "vandalism" or "destruction of property"). Maryland recognized that it is a bias crime to disrupt a religious meeting. Pennsylvania recognizes "paramilitary training" and "igniting racial violence" as part of their hate crime statute, but not bias against sexual orientation. South Carolina includes as part of its statute the wearing of masks to conceal individual identity on public property (Ellis 3).

With so many definitions of both "hate crime" and "domestic terrorism" out there, it's no wonder that they would meet up one day and mix. U.S. 
Attorney Lynne A. Battaglia declared at a Baltimore hate crime conference that the Oklahoma City bombing was a "hate crime" and that hate crimes are terrorist acts. ${ }^{5}$ The September 11,2001 , attack on New York and the Pentagon is frequently regarded as a hate crime by restorative justice advocates. ${ }^{6}$ Social scientists often use the terms hate crime and domestic terrorism interchangeably ${ }^{7}$ (Hamm, Future of Terrorism 76-77).

According to Jacobs \& Potter, the concept of hate crime is loaded with ambiguity because it is difficult to determine "(1) what is meant by prejudice; (2) which prejudices qualify for inclusion under the hate crime umbrella; (3) which crimes, when attributable to prejudice, become hate crimes; and (4) how strong the causal link must be between the perpetuator's prejudice and the perpetuator's criminal conduct" (Jacobs 11). However, a recent study indicates that the ambiguity is a product of the effect of institutionalized prejudice acting up on the forces of definition in the legal context. "Thus, the diffusion of hate crime policies resembles the diffusion pattern of many other policy reforms." (Grattet et al).

Some argue that black offenders who attack white victims are motivated by economics, not prejudice. ${ }^{8} \mathrm{~A}$ few have proposed removing crimes based upon anti-white prejudice from the definition of hate crime, ${ }^{9}$ while others propose adding crimes based upon anti-female prejudice: 
Feminist analysts and activists against violence all insist that violence against women must no longer be defined solely as a crime against an individual who happens to be female and is unfortunate enough to become a victim. Rather, this violence must be seen for what it is - a crime of misogyny, of hatred of women . . . feminist theorists would suggest that society's acceptance of patriarchal assumptions and structures also accepts and condones these violations of women's autonomy (Copeland and Wolfe 3).

This touches on another problem exacerbating hate crime: the pervasiveness of "everyday prejudice" of one type or another in a given society. Even the most liberal-minded white upper class activist against racism is enjoying privileges made possible by collective prejudice. "Proponents of white guilt explain that while whites may not necessarily be racist on an individual level, they live in a racist society that automatically grants them certain advantages at the expense of other people" (Monroy). Our basic civil rights paradigm does not go into detail regarding prejudice among European ethnic groups. "The contemporary multicultural discourse refers to 'Hispanics,' 'Asians,' and 'Africans' as if they were single homogenous groups without divisive ethnicities. These classifications disguise enormous differences, historic animosities, and prejudices" (Jacobs 18). 
Notes

${ }^{1}$ Hamm (1994) cites Heitmeyer, W. "Hostility and violence toward foreigners in Germany." Eds.T. Björgo \& R. Witte. Racist violence in Europe. New York: St.Martin's, 1993: 17-28.

${ }^{2}$ Hamm (1994) cites Aronowitz, A. A. "A comparative study of hate crime: Legislative, judicial, and social responses in Germany and the United States." European Journal on Criminal Policy and Research, 2. 1994: 39-64.

${ }^{3}$ Hamm (1994) cites Lo6w, H. "Racist violence and criminal behavior in Sweden: Myths and reality." Terrorism and Politica! Violence. 7, 1995: 119-161.; Witte, 1993.

${ }^{4}$ Hamm (1998) cites Ball, R., \& Curry, G. D. "Preliminary findings from National Report on Juvenile Hate/Bias Crime." Annual meeting of the Academy of Criminal Justice Sciences, Boston. March 1995.

5 Hamm (1998) cites A. Rosga from a work in progress entitled "Good cop/bad cop: Refashioning law enforcement as the thin blue line between bigotry and tolerance." According to Rosga, The conference took place three weeks after the bombing of the Alfred $\mathrm{P}$. Murrah Federal Building. Batiaglia was a keynote speaker.

6 From personal notes of the author, gathered during attendance at the Victim-Offender Mediation Association Conference, Portland, Oregon, 2001.

${ }^{7}$ Hamm (1998) cites Aronowitz, A. A. "Germany's xenophobic violence: Criminal justice and social responses." Ed. M. S. Hamm Hate crime: International perspectives on causes and control. Cincinnati, OH: ACJS/Anderson:1994, 37-70; Berk, 1994; Hamm, M. S. "A modified social control theory of terrorism: An empirical and ethnographical assessment of American neo-Nazi Skinheads." Ed.M. S. Hamm, Hate crime: International perspectives on causes and control. Cincinnati, OH: ACJS/Anderson. 1994: 71-90; Hamm, M. S. "Review essay on Jack Levin and Jack McDevitt's Hate crimes: The rising tide of bigotry and bloodshed." Journal of Criminal Justice, 22. 1994: 71-74; Kellett, A. "Terrorism in Canada: 1960-1992." Ed. J. I. Ross, Vioience in Canada: Sociopolitical perspectives. New York: Oxford University Press, 1995: 286-315; Levin, J., \& McDevitt, J. Hate crimes: The rising tide of bigotry and bloodshed. New York: Plenum, 1993; Ross, J. I. (1994). "Hate crime in Canada: Growing pains with new legislation." Ed. M. S. Hamm, Hate crime: International perspectives on causes and control. Cincinnati, OH: AC.JSIAnderson,1994: 151-172.

${ }^{8}$ Jacobs cites Marc L. Fleischauer, "Teeth for a Paper Tiger: A Proposal to Add Enforceability to Florida's Hate Crimes Act," 17 Florida State University Law Review 697, 706. 1990.

¿ Jacobs cites Carey Goldberg, "Neighbors Play Down Race, Seeing Act of Crazy Man," New York Times, Dec. 10, 1995, at 50; Pedro Ponce, "Some Question Use of Hate-Crime Laws by Victimized Whites," The San Diego Union-Tribune, May 5, 1994, p. A36; Marc L. Fleischauer, "Teeth for a Paper Tiger: A Proposal to Add Enforceability to Florida's Hate Crimes Act," 17 Florida State University Law Review 697, 706. 1990; Paul Butler, "Racially Based Jury Nullification: Black Power in the Criminal Justice System," 105 Yale Law Journal 677. 1995. 


\section{CHAPTER SEVEN}

\section{Hate Crime Law}

In the late 1980s, a significant increase in skinhead violence against

minorities led U.S. civil rights activists to pressure Congress for laws requiring the FBI to gather and publish hate crime statistics (Ellis; Hamm American

Skinheads). At the same time, 31 states enacted laws against bias or

harassment, including interference with religious worship, and against cross-

burning (Finn and McNeil 52). This political consensus introduced the term

hate crime into the lexicon of U.S. criminal justice administration and led

Congress to enact the Hate Crime Statistics Act of 1990. Under the act, hate

crimes are defined as

crimes that manifest evidence of prejudice based on race, religion, sexual orientation, or ethnicity, including where appropriate the crimes of murder, non-negligent manslaughter, forcible rape, aggravated assault, simple assault, intimidation; arson; and destruction, damage or vandalism of property. ... Bias would be reported when the law enforcement investigation revealed sufficient objective facts to lead a reasonable and prudent person to conclude that the offenders actions were motivated, in whole or in part, by bias. (UCR)

The act led to the enactment of Public Law 101-275, requiring that the

FBI gather data on hate crimes for an annual Uniform Crime Report (UCR).

The law stated that "hate crimes are not [to be considered] separate distinct offenses, but rather traditional crimes motivated by the offender's bias." 
Categories of bias were listed as "the victim's religion, race, ethnicity, or sexual orientation" (UCR).

The first officially-collected hate crime data were supplied in 1991 by 2,771 law enforcement agencies in 32 states. By 1993, data were collected by 6,865 agencies in 46 states and the District of Columbia. Intimidation was the most frequently reported hate crime, followed by property vandalism and simple and aggravated assault. The data show that a single incident of hate crime often produces multiple offenses, victims, and offenders. The most serious hate crimes were catalogued as "group projects," suggesting a conspiratorial motive for violence. The most frequent motive for hate crime in 1993 was race ( $62 \%$ of total incidents), and the most frequent victim was a black person. Religion came in second ( $17 \%$ of total), and Jews were the most frequent victims. Sexual orientation was third (11\%) and ethnicity was last, with Hispanics the most frequent victims. (Hamm, Future of Terrorism 70-72)

The controversy over which right is more important---to protect freedom of expression or to discourage hate crime by regulating hate speech---arose in the 1990 s and is best demonstrated in the evolution of two hate crime cases:

R.A.V. v. St. Paul in St. Paul, Minnesota, and State of Wisconsin v. Todd Mitchell.

In October,1989, Mitchell, a young black man, left a movie theater with a group of friends after watching the movie Mississippi Burning. A scene in the movie portrayed members of the Ku Klux Klan killing a black man. After 
walking out of the theater, Mitchell asked his friends if they wanted to "move on some white people" and about that time, a 14-year-old white boy walked by and Mitchell and his friends proceeded to catch the boy and beat him so severely, that he went into a coma. Mitchell was convicted of aggravated battery and sentenced to two years in prison. Under Wisconsin's Penalty Enhancement Statute, a hate statute similar to those in many states that boosted the offenses in which the victim was "intentionally selected" on the basis of "race, color, religion, disability, sexual orientation, national origin, or ancestry," Mitchell received an additional two years added to his sentence. ${ }^{1}$

In 1982, St. Paul enacted a local hate crime ordinance which created a new offense: bias-motivated disorderly conduct. The ordinance stated that anyone who "places on public or private property a symbol, object, appellation, characterization or graffiti" that "arouses anger, alarm, or resentment in others on the basis of race, color, creed, or religion" was guilty of the misdemeanor offense of disorderly conduct. In 1989, the city amended the law to specifically include a burning cross or a Nazi swastika in the prohibitions. (Jost 57)

Prosecutors invoked the St. Paul ordinance for the first time in R.A.V. V. St. Paul in 1990. A group of teenagers was charged with placing a burning cross in the front yard of Russ and Laura Jones, who had recently become the first black family to move into a predominantly white St. Paul neighborhood. The teenagers were also charged with violating the state's hate crime law. (57) 
One of the defendants was a skinhead, and his attorney decided to challenge the constitutionality of the ordinance. He did not challenge the state's hate crime law, just the local ordinance. "In a country that values free speech, we should not have a law that says that expressing certain ideas, however offensive they may be, is in itself a crime," the attorney argued. The judge who heard the case agreed and struck down the ordinance. But the Minnesota Supreme Court reinstated the law in January 1991. The Supreme Court construed the law to be narrowly defined in terms of "fighting words," or words that have "a direct tendency to cause acts of violence by the person to whom, individually, the remark is addressed." The U.S. Supreme Court reviewed the case in June 1991. The Anti-Defamation League filed a brief to defend the law. The prosecuting attorney argued that it's one thing for a cross to be burned at the corner of a street, but another if it's "right in front of the Joneses' house." (58)

The U.S. Supreme Court decision in 1992 revealed how clearly divided justices were on hate crime law issues. The justices voted unanimously to strike down the ordinance, but they divided into two camps with conflicting concurrences. Four justices decided that the ordinance was too broad and that it violated constitutionally protected forms of freedom of speech. Five justices, however, ruled on the basis that it was discriminatory because it targeted only specific types of bigotry - racial, religious, and sexual insults - but not on the basis of free speech. 
Less than 24 hours after the R.A.V. decision came down, Wisconsin's Supreme Court cast out its Penalty Enhancement Statute which, in effect, nullified the additional two years in prison that Mitchell ${ }^{1}$ had received in . In ruling the law unconstitutional, Wisconsin's Supreme Court cited in part the day-old R.A.V. precedent and argued that the necessity to use speech to prove motivation "threatens to chill free speech" and steps into the realm of "subjective mental thought." Two months later, Ohio dumped a 1987 law similar to that of Wisconsin, deciding that it was unconstitutional for a "thought crime" law to punish conduct based on subjective mental processes motivating behavior. (Stinski 110)

In the same week, the Supreme Court of Oregon voted unanimously to uphold one of its enhancement laws, arguing that since speech serves as evidence in other instances---the words "I am going to kill you," for example, in an attempted murder case--the enhancement law was constitutional. The court also argued that the law punishes the committing of certain acts and does not necessarily rely on speech. One could infer bias if every Saturday night a defendant traveled to Latino neighborhoods and assaulted a passerby who appeared to be Hispanic. The court wrote "There is a distinction between making speech the crime itself, or an element of the crime, and using speech to prove the crime." (110) Significant to this thesis is the argument concurring in R.A.V. v. St. Paul written by U.S. Supreme Court Justice J.J. Blackmun: 
Significantly, the St. Paul ordinance regulates speech not on the basis of its subject matter or the viewpoint expressed, but rather on the basis of the harm the speech causes. . . Contrary to the Court's suggestion, the ordinance regulates only a subcategory of expression that causes injuries based on "race, color, creed, religion, or gender," not a subcategory that involves discussions that concern those characteristics. The ordinance, as construed by the Court, criminalizes expression that "one knows... \{by its very utterance inflicts injury on\} others on the basis of race, color, creed, religion, or gender." In this regard, the ordinance resembles the child pornography law... which in effect singled out child pornography because those publications caused far greater harms that pornography involving adults" [italics mine] (Baird $63)$.

The most important development regarding hate crimes since then is the Supreme Court's unanimous ruling in 1993 to uphold the constitutionality of bias crime penalty enhancement laws. This ruling permits increasing sentences for convicted hate crime offenders, a reversal of the ruling by the Wisconsin Supreme Court in Wisconsin v. Mitchell. "The Mitchell decision removes any doubt that properly constructed bias crime laws are constitutional" (B. Levin 8).

In addition to the issues brought in these seminal cases, the opponents of hate crime laws argue that it is discriminatory to consider one murder to be more heinous than another, simply based on whether or not the murderer is a racist. "The horrendous crimes that provide the imagery and emotion for the passage of hate crime legislation [such as the hate crime murders of James Byrd and Matthew Shepard] are already so heavily punished under American law that any talk of "sentence enhancement" must be primarily symbolic." (Jacobs 13) 
The proponents respond that there is a difference between biasmotivated crimes and other crimes, and two of the differences are evidenced by the longer time it takes for victims to recover (Garnets $378, A P A$ ), and the fact that a bias-motivated crime is intended to intimidate an entire group of people (Finn 20). Crimes against gays and lesbians not only harm the individual victims, but instills fear in the entire community (Hernández 848). Victims suffer more intensely when targeted for crime because of membership in a targeted group (Herek and Gillis). According to findings by the National Institute Against Prejudice and Violence, victims of ethnic violence suffer 21 percent more trauma symptoms than other victims of similar crimes. (Stinski 111)

Though awareness of prejudicial attitudes in society have raised public interest and the establishment of hate crime laws, we may need to achieve a deeper level of collective introspection before we can be clear on what those laws should say and do. "While homosexuality was removed from the American Psychiatric Association's standard diagnostic manual in 1974, twenty years later, some mental health professionals and much of the public still thinks of homosexuality as a 'disease' needing a 'cure'" (Brenner 127).

Notes

${ }^{1}$ State of Wisconsin v. Todd Mitchell. 


\section{CHAPTER EIGHT}

\section{Typologies of Hate Crime Offenders}

In 1983, Jack McDevitt and Jack Levin created a typology of hate crime offenders. (Levin and McDevitt). The first category are thrillseekers who usually act alone. They are bored, and are looking for the excitement and power of assaulting someone who is not a member of their cultural or racial group. They generally choose their victims on a random basis. McDevitt and Levin found that, at the time of their study, about two-thirds of bias motivated activity fell into this category. The second category are reactors. Their bias motivated activities are often precipitated by a specific incident. For example, they'll direct their anger and frustration toward an 'outsider' who encroaches upon their neighborhood, means of livelihood, or way of life. In this way, victims are not exactly randomly chosen but the crimes against them are not necessarily pre-meditated. They are just in the wrong place at the wrong time. The crime is their message to members of the targeted group to stay out of the offender's neighborhood, church, school, or town. This type of bias motivated activity often escalates until the warning is heeded. It is estimated that a little over a third of hate crimes fall into this category. The third category is missionaries. They are on a 'mission' to eliminate all members of the targeted 
group, regardless if there has been any specific incident that precipitated the hatred. This is the rarest type, representing about one percent of all reported activities. These are offenders who are more likely to seek out or are easily recruited into recognized hate groups for organized activities. The harassment and violence perpetuated by hate groups like the Ku Klux Klan (KKK) or Oregon's Volksfront that promote racial genocide are exemplary of these types of hate crimes (Levin \& McDevitt).

The academic work on bias-motivated activity tends to focus on hate groups and extremist organizations, although such groups were responsible in the early 1990 s for only $3-7 \%$ of reported bias motivated activity. (52). The most historically recognized group in the United States is the KKK, but this organization has had many ups and downs since it became active in the 1940 s and is currently in decline (Blee 137). Another group (or group of groups) is on the rise, however, and is proving to be as or more troublesome than the Klan. ${ }^{1}$

Skinheads began making themselves known in London in the mid1960 s, but they weren't really as much focused on hating people as they were on venting their frustrations about lack of work, which they attributed to the influx of Indians, East Indians, and other individuals racially different from the majority of the Commonwealth. (Kleg 34) Skinheads first appeared in the United States in the late 1970 s as part of the punk rock scene, and were thrillseekers more focused on fashion than fascism. By the mid-1980s when it 
became clear to organized hate groups that these disenfranchised youth were ripe for the picking, Skinheads began aligning themselves as reactors with support from these groups. (Blazak, White Boys 985; Blazak, Ethnographic study).

Blazak developed a typology of threats or "red flags of strain" that aid in forecasting where hate groups are most likely to lurk to find vulnerable recruits. I think the typology is useful for the purpose of this thesis, so I include it here in full. Blazak says that skinheads experience the "strain" of perceived threats in the following four categories. In addition, Blazak lists possible localized changes that trigger reactionary responses to perceived threats:

(Blazak, White Boys 989):

1. Threats to ethnic or racial status

- growth in the minority student population

- minority student organizations or events

- shifts to multicultural curricula

- racial conflict in which the institutions appear to support the minority group

2. Threats to gender status

- conflict over female participation in male activities

- feminist activist groups

- anti-sexual violence events or programs

3. Threats to heterosexual status

- sexual minority organizations

- gay pride events

- inclusiveness movements or sponsored dialogue

4. Threats to economic status

- factory layoffs

- large employer downsizing

- high competition for manual labor or service sector jobs 
Blazak appears to be mostly in agreement with the Levin and McDevitt typology but has deconstructed it a little further in order to make predictions. This typology is useful not only for identifying where to find recruits before they are recruited (hopefully for the purpose of redirecting them away from joining hate groups), but also what one could expect to hear about (at least in part) when engaging in any form of dialogue with offenders resulting from a justice action.

The period in which most youths are active as skinheads lasts about six months. Those who remain in the movement for any appreciable length of time may become 'missionaries' and eventually move onto adult groups such as the Christian Identity Church (Kleg 43). Of 173 individuals indicted under the FBl's counterterrorism program during the 1980 s, 103 were members of or associated with right-wing groups frequently regarded as being part of the "Christian Identity Movement" (Smith 32). They were all American and the average age was 39 . The majority of them $(97 \%)$ were white males with no higher than a G.E.D. equivalent. More than half were unemployed or living below the poverty line, and nearly all came from rural areas of Arkansas, Idaho. Kentucky, Colorado, and Arizona (47).

In 1991, Sociologist James Aho analyzed reports of 51 murders related to U.S. right-wing activity between 1980 and 1985 . He found that about half involved participants in the Christian Identity Movement. Aho created a typology of Christian Identity members. He divided them up into two camps: 
the "hedge-hogs" (grand theorists) and "foxes" (empiricists). Hedgehogs "are able to fit events as diverse as earthquakes, venereal disease, and commodity prices into an overarching theoretical scheme" (Aho 17). In contrast, foxes are concerned with ordinary problems like school textbooks and sex education. He found that is the hedgehogs who ignite trouble, and the foxes conform (17).

In another typology study, Aho found, like Smith, that the hedgehogs are "exceptional only in their ordinariness" (67). The most violent among them were average white men who had been "Boys' State representatives, high school yearbook editors ... rock 'n' roil musicians ... one-time teen athletes, a champion amateur golfer, and a high school teacher with a masters degree in counseling" He found them to be "likable" and "good workers" who were "very polite" as young men (66).

Although there are youths in neo-Nazi movements who can count as an influence a childhood of trauma and abuse, this is not always the case and it is probably unwise to make that assumption about Skinheads. Researchers have found that a critical factor in the development of the frustration that leads to violence among neo-Nazi youth is information transmitted via the Internet, racist books, journals, films, and most important, music (Hamm, American Skinheads; Wooden and Blazak 216).

Hamm interviewed 36 U.S. skinhead leaders between 1989 and 1992. His findings dispute the stereotypes of skinheads as undereducated products of child abuse. "The Skinheads were predominantly young white males from 
working-class backgrounds who reported no early childhood trauma nor any abuse by their parents. The majority of them were either enrolled in high school, were high school graduates now working blue-collar jobs, or were attending a university." (Hamm, American Skinheads 83) But it could be argued that these findings are more a reflection of the typology of a skinhead group leader than the average member ${ }^{2}$ who calls himself a skinhead because he walks the walk and talks the talk. Based on his observations, Hamm came to define the Skinhead movement as a "terrorist youth subculture" (84). Thus, we have one more definition to add to the mix.

\section{Typology of a Reformed Offender}

To segue into the next part of my thesis, I would like to include briefly another typology here: the reformed hate crime offender. For the purpose of determining how (or if) a restorative justice approach is useful in hate crime cases, it is just as important to know how a young person gets herself out of a life of hate as how she got in. For it is in the reformative process that accountability for one's actions- a cornerstone of restorative justice - is realized.

It begins with flash of insight into the stark reality of what one has become, which leads to an identity crisis. After abruptly leaving the life of hate behind, there comes a dark long journey through immense guilt and profound 
self-loathing. And then, finally, comes a long, upward climb of personal transformation (Ezekiel; Greason; Hasselbach).

The first stage - the flash of insight - is so profound and personal that it is never the same from person to person. Blazak, who co-founded Oregon Spotlight, an organization that helps Pacific Northwest youths leave hate groups, describes what it was like when that flash hit one Nazi skinhead who called him for help out of the movement:

I [Blazak] asked what turned him around, and he said it was an offhanded comment I had made about peanut butter being invented by George Washington Carver, a Black man. "Man, I love peanut butter and I'm not going to give it up just so I can be a good racist!" he told me. (Blazak, White Boys 999)

Compare that to the flash that hit David Greason, who was a leader in the racist British National Front and in the violent National Action (NA) of Australia:

I don't think you drop intolerant politics because you've realized that The Protocols of the Leamed Elders of Zion is fraudulent or that Hans Eysenck's theories on race are Eurocentric. You can't simply figure your way out of a life. It really falls apart when you're willing to give people the benefit of the doubt. It comes when you're sitting in a cab with some Vietnamese taxi driver and you're remembering those lines you've always trotted out when you're in an argument-Look, all people prefer their own, and it's nothing to do with hatred, but everything to do with what people have in common except this time you're thinking, on a one-to-one basis, here, now, in this RSL cab, could I have more in common with this Vietnamese driver than I have with a National Action member who keeps guns under his bed? [italics mine] (Greason 298299).

and the flash that hit Ingo Hasselbach, the former leader of Germany's most formidable neo-Nazi organization: 
I woke up the next morning to the news on my clock radio; three people had been burned alive in a neo-Nazi attack in the town of Mölln in northern Germany. . . . Oddly enough, considering the thousands of attacks that had occurred in the last couple of years, this was the first with fatalities. . . I I felt a certain boundary had been overstepped. . . I I told my Komerads point-blank that this was a sad and awful event and we must at least re-think our methods if they were to lead to this .... Something had permanently snapped inside of me, and I couldn't think that way anymore. I couldn't think of these Turks just as foreigners. They were also people - dead people with families [italics mine] (Hasselbach 322-333).

The differences in these flashes of insight reflect what makes each one of these men individuals. But what is the same between them - and with everyone, racist or not - is that we are all capable of moments of clarity that can lead to seemingly impossible transformations.

Notes

${ }^{1}$ There are many groups and many groups of groups, but I have chosen only one for the purpose of comparing typologies.

${ }^{2}$ There are also 'angry white girls' in the hate movement - though they are in the minority, their number are increasing exponentially. Kathleen Blee has written for many years about racist women and what motivates them to join hate groups, and has found that they also do not fit the stereotype of the undereducated and abused (Blee 2002). Her most recent work features many "conversion stories" by young women who join hate groups. 


\section{CHAPTER NINE}

Restorative Justice Principles

Unlike my literature review for the topic of hate crimes, I did not find what could fairly constitute well-established "seminal works" that represent well all sides of a critical discussion of restorative justice. The field as an academic pursuit is new, and much of the literature up until the last few years has been written by restorative justice practitioners. I did find a few sources that critically compare restorative justice theory to political science theories, and a few sources out of Australia and the United Kingdom that were critical of either principles or practices, and I included these sources in this section.

For the most part, I pieced together parts from several sources to present a variety of definitions and principles underlying restorative justice, and no doubt some of these will change as we speak, since the field itself is in a state of flux. I thought it would be best to provide the variety and dynamic nature of principles in this field, because it is an important observation for the purposes of this thesis. I also confined my literature review to those works which were mostly relevant to my thesis.

For this section on "principles" I tried to separate those principles that constitute a working philosophy of restorative justice from those that seem to apply mostly to practice, and I address the latter in the next section on 
"Restorative Justice Practices." This separation seemed to occur naturally out of the literature, with more literature devoted to principles of practice than to a philosophical standard driving theory. To guide my decision as to which pile the source work should go into, I observed whether or not the source work and/or author went from the direction of theory to practice, or practice to theory. The former material is presented in this section, and the latter in the next section.

\section{Conflict Theories}

Nils Christie is one of the modern philosophers to address the problem of how we handle conflict in contemporary times and especially how it is handled in the dominant criminal justice paradigm. He argues that conflict has not only been captured by the State but subsequently defined by the State, attributed with a measure of seriousness (e.g. first degree murder, second degree, murder, etc.), and is then relegated to various procedures depending upon that level of seriousness. This system of processing through legal definitions and abstract procedures has resulted in the depersonalization of conflict which replaces the views, perceptions and wishes of those actually involved in the conflict (Conflict as Property 12). These views are well supported when one examines the literature on victims, their role within the traditional court process and how they view courts as a means of resolving conflict. The way that Western legal systems handle crime compounds the 
disempowerment that victims feel, first at the hands of offenders and then at the hands of a professional, remote justice system that eschews their participation. The lawyers, in effect, "steal our conflict" (33).

As Emile Durkheim ${ }^{1}$ before him, Christie is a proponent of the perspective that conflict possesses inherent positive benefits. However, as the above discussion illustrates, the appropriation of conflict by the State has resulted in conflict losing many of its intrinsic and socially reinforcing values (Conflict as Property 16). The opportunity for the victim to publicly express the personal impact the offender's behavior may have had is not only lost, but more unfortunately, depreciated, as is the opportunity to express outrage over what has occurred. The victim is the brunt of the consequences for breaking the state rules and expressing the outrage they well deserve to feel. Rather than perceiving outrage as reinforcement for the importance of maintaining societal norms, the hurt and anger of victims are dismissed as "vengeful", "retributive" or "punitive" and at best "left to the experts." (16) The value of conflict as a personal expression, then, is entirely negated.

Christie's lament has been echoed in recent criminological discourse after resurgence in debate as to "What is the appropriate role and voice of victims of crime?" Once marginalized, victims of crime are now argued as integral if the criminal justice system's response to crime is to be at all effective (Shapland et al. 1). The refocus on victims as crucial, if not central to responses to crime is a strongly held principle in restorative justice. 


\section{Defining Restorative Justice}

Just as defining "hate crime" is at the center of debate in literature about hate crime, a definition of restorative justice is problematic. Also likewise, it depends on who you ask, and a good deal of definitive terms are dependent on contrast: restorative justice is that which retributive justice is not.

In essence, advocates of restorative justice argue that victims must participate in the process if justice is to be effective. The philosophy, theory and practices of restorative justice are shaped by the fundamental belief that the impact of a crime can only be resolved between and by those who are affected. Theoretically, practices under the umbrelia of restorative justice involve the establishing of settings and procedures whereby those most affected by the incident, namely the victim and their offender and supporters of both, meet and discuss the incident, its consequences and how best to deal with the harms and issues arising from the crime. Through dialogue processes, reparations are negotiated and forgiveness and healing are initiated (Sharpe).

There are two important features often associated with restorative justice: 1) victim and community are participants in the administration of justice, and 2) offenders are members of and accountable to the community. The emphasis on the victim is particularly important. Advocates of restorative justice have been highly critical of the criminal justice system for neglecting the 
victims of crime and focusing on the punishment and rehabilitation of offenders. Meeting the offender addresses certain victim needs (e.g., emotional satisfaction and personal healing) and brings the victim's perspective into the administration of justice. As a result, restorative justice provides a sense of victim empowerment (Sharpe).

Daniel Van Ness describes the basis premises for restorative justice thusly:

1) Crime is primarily a conflict between individuals resulting in injuries to victims, communities, offenders and their relationships. Only secondary is it lawbreaking.

2) The overarching aim of the criminal justice process should be to reconcile parties while repairing the injuries caused by crime.

3) The criminal justice process should facilitate active participation by victims, offenders and their communities. It should not be dominated by the government to the exclusion of others. (Van Ness 23)

This particular set of standards is repeated frequently in restorative justice articles and papers. From there, definitions begin to vary.

In the light of restorative justice, crime is viewed primarily in an interpersonal context. Ideally, conflicts are settled outside of courts and are considered to be a matter for handling within the victim's and offender's kin and community, as was done in days of old (Zehr, Lenses 99-100). While the traditional "retributive justice" views crime as a violation of the state and its focus is on punishment of the offender, restorative justice views crime as a breakdown in relationships between offender, victim and community. "Crime is 
a violation of people and relationships. It creates obligations to make things right. Justice involves the victim, the offender, and the community in search for solutions which promote repair, reconciliation, and reassurance" (181).

Restorative justice is also a distinctively different model from the "rehabilitative approach" which focuses on the treatment of the offender, and which sees individuals not as social actors but as objects (Walgrave 230).

Sometimes restorative justice is defined in terms of how it should be considered as a thought process, rather than what it does in action. Restorative Justice is said to be "a way of thinking" about responding to the problem of crime, and a set of values that guides decisions on policy, programs and practice (Pranis). Victims' involvement and perspectives are essential to the processes of defining the harm of each crime and identifying how that harm might be repaired. A comprehensive restorative response to crime engages the community as a resource for reconciliation of victims and offenders, and as a resource for monitoring standards of behavior. "A restorative response to crime is a community-building response" (Pranis).

Transformative justice, healing justice, satisfying justice -- Susan Sharpe includes all of these terms under her umbrella of the conceptual markers that guide restorative justice. Sharpe states that restorative justice is "justice that puts energy into the future, not into what is past" (Sharpe 7). Restorative justice invites full participation and consensus, sets out to heal what has been broken, seeks full and direct accountability, reunites what has 
been divided, and strengthens the community to prevent further harms (7). "Restorative justice is an orientation, not a program" (19).

The "restorative" in the term refers to the principle of reuniting what was divided, and regaining good graces. Community divisions that occurred as a result of the harm inflicted begin to fuse in resolution. Sharpe uses the word "reintegrate" to describe this process, ${ }^{2}$ highlighting the importance of reintegration for both victim and victimizer. The victimizer is forgiven and welcomed to continue in relationship with the community. For the offenders, it is important to feel the community's continued support and faith in their ability to avoid doing further harm. For the victim, it is important to reintegrate by losing the "victim" status, which can lead to a type of shunning behavior all its own in a given community. In summary, for both parties it is important to regain full identity, no longer primarily identified in terms of the incident (11).

An important oft-repeated principle of restorative justice is strengthening of the community so as to prevent future harm. But most principled-based accounts do not elaborate on how the community is strengthened by the process. This is one area where Sharpe's presentation of restorative justice goes a step beyond some of the more common descriptions. Most are interested in addressing the particular issue or harm "on the table" in an inclusive manner. Sharpe argues instead that restorative justice has to look at structural issues. It has to work actively toward a more just future, essential in discussing sociopolitical conflicts in the community. 
She writes that, "people who have long felt excluded from the community through prejudice, poverty, or unemployment have no place to come back to after apology and reparation. They also may have little interest in feeling connected with and responsible to the community that has shut them out" (52).

This is an important principle to debate when determining the boundaries between what constitutes restorative justice as a professional practice and restorative justice as a human rights campaign. Ruth Morris writes that "restorative justice is not enough if it doesn't address, fundamentally, the issues of racist and classist injustice which lies at the root of every one of our systems" (R. Morris 17). These forces have already created conditions of inequality, enacted in job markets, standard of living, and inaccessible opportunities. Biases in the power structure often prevent participation from minorities. La Prairie writes that justice structures such as sentencing circles need the support of "larger arms of government" on "bigger fronts such as job training and education" or else, "these alternatives will see relatively modest success" (530).

\section{Roots of Restorative Justice Principles}

The early concepts of restorative justice rested upon the involvement of the community as a party in the process. Ideally, restorative justice calls forth the empowerment of the community (McCold 90). It is communitarian ideals such as public problem-solving and citizen participation that lie at the heart of 
restorative justice (Bazemore, Three Paradigms 44). Advocates often report that restorative justice has roots in an ancient way of settling disputes (Galaway \& Hudson 1; Braithwaite, Crime, Shame; Strong and Van Ness; Zehr).

New Zealand Judge Frederick W.M. McElrea characterizes three distinct restorative justice principles: the transfer of state power to the community, a mechanism for negotiated community responses to crime, and the participation of victim and offender in a process of healing (McElrea 120). In an explicit connection to Aboriginal justice, he writes, "it is these elements of restorative justice that link the New Zealand initiative [family group conferencing] with Maori concepts of justice based on restoration of harmony within a network of family, community, and tribal relationships" (122).

This example represents a widespread view in the progressive restorative justice community that restorative justice is fully compatible with Aboriginal justice, and is in fact, an extension of it, as was discussed in the section of this paper entitled "Background: Restorative Justice." However, recent criticism argues that this claim is baseless (Daly, The Real Story) ${ }^{3}$

\section{Reintegrative Shaming}

An interesting theoretical contribution borrowed from aboriginal justice models has been the idea of re-integrative shaming. This concept views not the fear of state punishment as the most effective method of deterrence, but 
the anticipated experience of personal rebuke from those we care about; the experience of shame. Shame can either be stigmatic, when it locates the 'cause' in the offender, or re-integrative, when it maintains that the offender is an essentially decent person (Masters 237).

John Braithwaite 's theory of "re-integrative shaming" maintains that in any restorative justice setting -- and in criminal justice, for that matter -- a distinction must be made between the offender and the offender 's behavior, so that exclusionary shame can be avoided. He argues against a preoccupation with finding theories for why people commit crime. He suggests, instead, asking the question: Why do most of us not commit crime and comply with rules and procedures? Braithwaite's idea is that most people are deterred from committing crime on two levels: internally, through their sense of right and wrong; and externally, by the threat of disgrace or condemnation by people with whom they have a significant relationship (Crime, Shame 23). Therefore, in order to maintain an offender 's existing social bonds, any condemnation should be in the context of care and respect. This is consistent with restorative justice principles; however, there are dissenting voices in the field who say that shaming of any kind has no place in the healing process.

The philosophy behind restorative justice is "making things right." (An Immodest Theory 23) This is achieved by condemning the behavior of offenders while preserving their dignity. For many offenders, it is a harsher 
sentence to have to face their victims, community and family, than to spend time in a correctional facility.

\section{Contrasting Restorative Justice \& Retributive Justice}

The following are interesting examples of how restorative justice is defined in terms of how it contrasts against its opposite: retributive justice. "Restorative justice is a normative theory and a reform movement attempting to bring dialogue and reconciliation between victim, offender, and community to the center of criminal justice practice" (Dzur and Olson 2) ${ }^{4}$ Restorative justice is critical of the dominant retributive and rehabilitative models of criminal justice and rejects professionalism. Instead, restorative justice draws on diverse aboriginal practices of conflict resolution (2). Restorative justice brings to light major flaws of the current system: that it regards offenses as against the state (rather than against people), that it is mired in procedural rules, that the moral force behind punishment is the authority of the state rather than the need to be accountable to those who have been harmed, and that the punitive needs of the state overrules the needs of the victim (2). In summary, the current system is flawed because it abstracts the crime away from the actual experiences of victim, offender, and community (2).

Restorative Justice addresses the harm that communities suffer as a result of threats to security and notions that individuals have the right to feel safe in their community. However, harm to a community is a vague notion and 
restorative justice proponents have not provided an adequate basis for determining what is meant by "communal harm" (von Hirsch 675).

Restorative justice is not just a focus on communal \& individual harm, however. It is a principle that guides a change in the relationship between communities, individuals and state. It calls for a shift in the "essential role of the citizen from service recipient to decision maker with a stake in what services are provided and how they are delivered" (Bazemore, The Community 334).

The aspect of community participation in restorative justice is similar to idealizations of public discourse in deliberative democratic theory in the field of Political Science (Dzur and Olson 3). In deliberative democratic theory, public discourse is to be held in the "wild public sphere," unaccountable to the rules and procedures of the "formal public sphere" of legislatures (Habermas 166). James Fishkin adds that ideal deliberation requires participation by a random sample of citizens that have the opportunity to discuss the matters at hand with professionals and politicians. However, the deliberations are directed by the people, not by the professionals or politicians (Fishkin 132-134). In both deliberative democratic theory and restorative justice principles, a key virtue of public participation and dialogue is the airing of values, something seen as missing from the mainstream. 


\section{Contribution from Aboriginal Justice Principles}

Some authors are very cautious about the potential of the restorative justice approach. It has been claimed, that the enthusiasm for indigenous justice systems, such as the one which inspired Family Group Conferencing in

New Zealand, is a fashion and irrelevant for a different cultural context (Brogden 15). There is merit in this argument. It is worth consideration whether or not aboriginal justice can be transported to "the global village." Consider this example of how aboriginal justice worked more or less in some native traditions in Canada:

In the distant past, a person who committed a crime was taken to the centre of the village and publicly stripped of all their possessions and sent from the village to with only what he or she wore. In a year's time they could return and bring gifts to the person or people they had committed the crime against. (As told by Twylah Hurd Nitsch to Kulchyski et al 88)

It is debatable whether or not this sort of simplistic solution to the problem of crime could be exercised in the 21st century. However, applying the principles of aboriginal justice can and do apply with some degree of successful universality. A frequent interpretation of Aboriginal justice explains it in terms of healing, or returning balance to a person, situation or community. This understanding of justice is a natural progression of a worldview based on relationships, holism, and cycles. Patricia Monture-Okanee explains that "harmony, not justice is the ideal" (Reclaiming Justice125). Personal balance 
is sought for the offender and victim, as well as communal balance, restored through strengthened connections.

Aboriginal peoples differ in the ways they understood and administered justice traditionally. As is true with other groups of diverse peoples and cultures, there is no one method that could be said to describe Aboriginal traditional justice in entirety. However, common themes have been identified by Aboriginal people and scholars, principles that stand in distinction from mainstream justice. For instance, Monture-Okanee suggests that justice, truth, tolerance, understanding, and equality would have been essential to traditional Aboriginal justice (126).

One distinction that enjoys such consensus was foreshadowed by Sharpe's explanation of justice as orientation, not process. However, Sharpe needs to extend her definition a little further to reflect an Aboriginal principle: beyond orientation to action. This is the first and central point concerning Aboriginal justice. Justice is not a program to be administered, it is a lifestyle, a belief system, and a worldview. Rupert Ross passed on a message he heard repeatedly in his investigation of Aboriginal traditional justice:

Within traditional Aboriginal understandings, a justice system involved far more than simply controlling how disputes were handled after they broke out. Instead, the primary emphasis was on teaching individuals from birth how to live together in ways that avoided or minimized them in the first place. (255)

Thus, a discussion of traditional justice necessitates examining how to live the "good life" envisioned above. Monture-Okanee affirmed this 
relationship when she explained the expression for "law" in her Mohawk language. She said that to her people, the closest thing to "law" meant, "the way to live most nicely together. (Thinking About AJ 227)." In this context, restorative justice appears not only to be inspired by indigenous systems but it is at the same time re-activating Western legal traditions, such as the traditions posited in the deliberative democracy model mentioned previously in this section. This is not to glorify forms of community justice that have the threat of violence attached to them (Davis 19). Community justice is simply a justice system that is controlled by the local community and it does not have to be restorative in its approach. Restorative justice has to be careful to use traditions of community justice only if they reflect restorative and non-violent principles.

\section{Critical Views}

The scant critical literature of the last few years focuses on practices and program evaluations. I found two recent papers by scholars in Australia that touch on principles. Michele Venables interviewed victims who had undergone a form of restorative justice conferencing in Australia, to determine victim satisfaction with the process (Venables). She found that up until the time of her study, research findings on conferencing models, carried out primarily by restorative justice practitioners or trainers, had largely concentrated on presenting positive findings. Studies cited victims as being 
highly satisfied with the process, pleased with the outcomes and feeling 'restored' as a result of the conference. ${ }^{5}$ "Of concern is that the relatively few negative aspects of conferencing have not been reported in any detail" (77). Venables found that, in fact, the components of the restorative justice action that were most cited by proponent studies as being the key to victim satisfaction were not supported by the findings from her interviews with victims. For example, proponent studies concluded that victims feel "restored" after receiving apologies from their offenders. But Venables found no evidence for this, and in fact cited from interviews that victims often felt the apologies were coerced by the restorative justice practitioners (79).

The "continual broadening of the scope of what defines restorative justice" has recently been criticized (Daly, The Real Story), and is perhaps partially implicated in what Mark Umbreit calls the "McDonaldization" of restorative justice practices such as victim-offender mediation (Umbreit 105). Often the term is associated with the resolution of broader political conflicts such as the reconstruction of post-apartheid South Africa, post-genocide Rwanda, and post-sectarian Northern Ireland. ${ }^{6}$

One reason that the definition is problematic is the idea of restorative justice has become so popular, the term is now applied after the fact to programs and policies that have been in place for some time, or it is used to describe reputedly new policing and correctional policies. ${ }^{7}$ Adding to the problem is one of lack of objective empirical evidence since so much of the so- 
called "objective studies" have been carried out by high-profile advocates. ${ }^{8}$ Until careful, objective empirical work is carried out, we cannot be certain what is going on or the degree to which any of these newer or repackaged practices could be considered "restorative" (Daly, $\underline{\mathrm{RJ} \text { in Diverse Societies). }}$

Regardless of how practices are reported, restorative justice apparently aims to restore harmony based on a feeling that justice has been done. Restoring harmony alone, while leaving an underlying injustice to fester unaddressed, is not enough (Braithwaite, $\mathrm{RJ} \&$ a Better Future). "Restoring balance" is only acceptable as a restorative justice ideal if the "balance" between offender and victim that prevailed before the crime was a morally decent balance. "There is no virtue in restoring the balance by having a woman pay for a loaf of bread she has stolen from a rich man to feed her children" (RJ \& a Better Future). Restoring harmony between victim and offender is only likely to be possible in such a context on the basis of a discussion of why the children are hungry and what should be done about the underlying injustice of their hunger. This is the sort of situation that demonstrates the need for clear boundaries of theory, definition, policy, and practice of restorative justice, so that practitioners do not find themselves in one moment acting as neutral mediators and in the next moment as biased activists.

Restorative justice cannot resolve the deep structural injustices that cause problems like hunger. But we must demand two things of restorative justice here. First, it must not make structural injustice worse.... Second, restorative justice should restore harmony with a 
remedy grounded in dialogue which takes account of underlying injustices. (RJ \& a Better Future).

It is this accounting for underlying injustices that is important to a realization of what restorative justice may or may not be able to accomplish in the arena of hate crimes, and which I will address in my findings based on this literature review.

\section{Notes}

${ }^{1}$ Among other aspects of conflict theory supported by Durkheim, one aspect relevant to this thesis is that man is an animal with strong emotional desires and susceptibilities, and that particular forms of social interaction designed to arouse emotions operate to create strongly held beliefs and a sense of solidarity within the community through participation in these rituals of social interaction.

${ }^{2}$ I have heard said in restorative justice circles that there may be a need for new terminology to reflect what has been learned about the process. One such term l've heard more than a few times is "reintegrative justice." Another is "transformative justice." I am currently working on a project with a group of former (disillusioned) attorneys, under the heading of "transformative law."

${ }^{3}$ See "A Brief History of Restorative Justice" earlier in this paper for more information on aboriginal roots of restorative justice principles.

${ }^{4} /$ think it is interesting to note that Dzur and Olson are political scientists who define restorative justice as a theory and a reform movement, rather than a set of principles. It is indicative of the way definitions vary according to field of interest.

${ }^{5}$ Venables cites the following: Hayes, H. \& T. Prenzler \& R. Wortley. Making Amends: Final Evaluation of the Queensland Community Conferencing Pilot. Griffith University, Brisbane, 1998; Umbreit, Mark. Victim Meets Offender. The Impact Of Restorative Justice and Mediation. Criminal Justice Press: New York, 1994; and Strang, H., G.C. Barnes, John Braithwaite \& L. W. Sherman (1999) A Progress report on the Canberra Reintegrative Shaming Experiments (RISE). <www.aic.gov.au>.

${ }^{6}$ Daly cites the South African Truth and Reconciliation Commission (1998) The Report of the Truth and Reconciliation Commission. <http://www.org.za/truth/report>; Christodoulidis, Emilios (2000) "'Truth and reconciliation" as risks', Social \& Legal Studies 9(2): 179-204; Dignan, Jim (2000) Restorative Justice Options for Northern Ireland: A Comparative Review. Belfast: The Stationery Office Bookshop: 12-13; Drumbl, Mark A. (2000) 'Retributive justice and the Rwandan genocide', Punishment \& Society 2(3): 287-308.

${ }^{7}$ Daly cites Carol La Prairie (1999), "Some reflections on new criminal justice policies in Canada: restorative justice, alternative measures and conditional sentences," Australian and 
Notes, cont.

New Zealand Journal of Criminology 32(2): 139-52; and Adam Crawford (2001), "The prospects for restorative youth justice in England and Wales: a tale of two acts," in K. McEvoy and T. Newburn (eds.) Criminology and Conflict Resolution, London: Macmillan.

${ }^{8}$ Mark Umbreit, social worker and director of the Center for Restorative Justice \& Peacemaking at the University of Minnesota, is well cited in the field, though careful examination reveals that his body of work consists mostly of self-directed program evaluations which are ultimately always favorable. 


\section{CHAPTER TEN}

\section{Restorative Justice Practices}

This section of the literature review concentrates on the most common practices of restorative justice. There are some notable exceptions to the literature I use for this section. There are proponents of restorative justice that have written extensively on one sort of practice or another and who are prolific in the field. However, in my research I found some of these prolific writers were also professional practitioners and often spoke of the entire realm of one practice or another to be wholly represented by their own experience. I left out these professional assessments and instead looked deeper for critical scholarship. I also looked for voices from a culturally diverse set of authors, since the principles of restorative justice are often represented as relying on such diversity. Finally, I concentrated on aspects of practices or whole practices that had relevance to my inquiry.

Absent from this part of the literature review is the practice of truth \& reconciliation commissions. I covered this practice as a matter of historical record (see "A Brief History of Restorative Justice").

Tony Marshall offers a much-cited workable description of restorative justice in practice: 
Restorative justice is a process whereby all the parties with a stake in a particular offense come together to resolve collectively how to deal with the aftermath of the offense and its implications for the future (qtd. in Braithwaite Immodest Theory).

Restorative Justice advocates support a form of alternative discourse outside the mainstream of regular criminal justice rhetoric, where victims can communicate with offenders, and where offenders can take accountability for their actions in a personal meaningful way. Nils Christie describes the setting for this type of alternative justice that occurred in a Tanzanian village. I include it here in full not only as an interesting example of how this form of discourse works, but also to show an example of what is considered "village justice":

1. The parties....were in the center of the room and in the center of everyone's attention. They talked often and were eagerly listened to.

2. Close to them were relatives and friends who also took part. But they did not take over.

3. There was also participation from the general audience with short questions, information, or jokes.

4. The judges, three local party secretaries, were extremely inactive. They were obviously ignorant with regard to village matters. All the other people in the room were experts. They were experts on norms as well as actions. And they crystallized norms and clarified what had happened through participation in the procedure (Conflict as Property).

\section{Victim-offender Mediation}

By far, the most widely used practice of restorative justice in the United States is victim-offender mediation. What differentiates the contemporary practice from the example above is that the "experts" are simply the victim(s) 
and offender(s) themselves, and the role of mediator(s) is to take part but not to take over.

The process goes more or less like this: The victim and offender sit down at the table face to face, usually at a public meeting space, and the mediator is there to keep the process going and to help participants keep the focus on repairing the harm. The victim and offender both have equal time to tell their stories of what happened and how the crime affected them. Then they work out how to repair the harm. This resolution can take many forms: restitution, community service, written or verbal apologies, or they can be as creative in their agreement as they want to and can agree to be. In the case of a dialogue revolving around serious or severe crime, such as malicious harassment or murder, the process can also include many separate meetings between the mediator and the victim and offender, individually, to make sure that once the mediation takes place, there is no or little potential for re-harming the victim. What these processes have in common is that they are all victiminitiated - there is no standard model in the U.S. that would have practitioners approaching victims due to requests by offenders. Some prisons allow the offender to make a statement of interest in participating in victim-offender dialogue, but the statement is filed away for the day when, and if, the victim makes the request (Sharpe).

Two approaches are currently in vogue in the U.S. and Canada as far as how a mediation is conducted. I have been trained and have conducted 
mediations using both approaches so I will describe the processes from personal experience. One approach is to concentrate on neutrality by having the mediator enter the mediation "cold," meaning that s/he has no prior contact with victim or offender before entering the mediation space. In this scenario the mediator's role is to make sure the dialogue is fair and balanced, meaning that both sides (victim and offender) have a chance to tell their stories and respond to issues that arise. The mediator shows no overt emotion except that which would be expected from hearing stories for the first time, but even then the issue of maintaining on air of impartiality is crucial. In the second approach, the mediator takes on a mediation "case" and meets with the participants ahead of time, each in their own settings, to discuss their concerns. By the time the mediation takes place, the participants have (hopefully) developed trust for the mediator, each in their own time, and the mediation itself progresses in a less formal, more relaxed manner than the prior scenario. This is considered to be the "humanistic" approach while the former is considered to be the "neutral" approach by proponents.

In my view, what differentiates these approaches is the issue of partiality: the "neutral" approach strives for impartiality, while the humanistic" approach strives for partiality equally towards all. This is an approach called "balanced partiality" which is described by Yarrow, in his work as a Quaker conciliator, as "a sensitivity to all the individuals and groups involved in a dispute:" 
[The conciliators] treat the people with whom they are talking ... with respect and attention. They really listen to them and I mean by that that they still the noise and confusion of their own thoughts and emotions and open themselves up completely to what the other person is trying to say, or perhaps feeling without expressing. This kind of listening ... has a very real effect on the person being listened to. He becomes calmer, himself more receptive and open to ideas (Yarrow 265).

The "judges," or any criminal justice officials of any kind, are usually not a part of victim-offender mediation itself but are participants in the decision to refer offenders (especially youth offenders, in the U.S.) to restorative justice programs. The clarification process Christie observed in Tanzania is at the heart of the contemporary practice, with dialogue focused on clarifying roles, accountability, and how to repair the harm. But restorative justice practices also include family group conferences, circle sentencing, and restitution panels. All the practices have in common that they are dialogue-driven and they seek to produce a resolution to harm or conflict that is satisfactory to all concerned. The goal of victim-offender mediation is to preserve ongoing interpersonal relationships more successfully than standard court procedures because it is assumed that the parties desire to preserve coherence within a community and their ability to influence each other.

Restorative justice arose out of a desire to involve victims in the criminal justice process. It is hoped that mediation will allow the offender an opportunity to understand what he or she has done by directly (or sometimes indirectly) hearing the victims tell their stories. This process can be painful for the victim, but the offender also feels pain because the process can involve 
confronting excuses so the offender realize the harm he or she created. The hope is that the process is a catalyst for changing behavior, and that victims and offenders can achieve consensus as to the true consequences of the crime and what is needed to restore balance. Mediation allows for "the airing of (victim's) grievances ... more complete than in court, as the range of relevance is extremely broad" (Wright 23).

I think if I would have had to actually face the people whose homes I burglarized, when I was a kid...I think it might have changed my life. Maybe I would have figured things out sooner - maybe I wouldn't be an ex-convict now. -- convict in Washington County, Minnesota (Nicholl 120)

Not all mediation processes, however, have as their objective to provide a service to victims and offenders to explore the personal harm of a crime. Sometimes it's just a matter of alleviating overcrowded court systems while keeping within a semblance of justice. Criticism centers on the mediation serving the interests of one party more than the other, and benefiting the justice system more than either of the parties. The first complaint is still a dominant criticism of mediation in cases of domestic abuse. (Clarke).

Neighborhood justice centers -- which are sometimes referred to as restorative -- are more settlement driven than dialogue driven, focusing on outcomes that fit the system rather than providing a dialogue process that in itself is reconciliatory. For this reason, many mediation programs are not necessarily consistent with the values of restorative justice. (Nicholl 116) 
The first Victim Offender Reconciliation Program (VORP) was set up in 1976 in Ontario, Canada, with the first known contemporary case of victimoffender mediation (see "A Brief Restorative Justice" in this thesis). Elkhart, Indiana, followed up with a VORP that began mediation under a new paradigm. "The old paradigm's focus is on blame-fixing for the past; the new one, while encouraging responsibility for past behavior, looks to the future, problem-solving the obligations created by the offense" (Wright 28). The Elkhart VORP was, therefore, probably the first time the concepts of mediation and the principles of restorative justice were brought together. Victim-offender mediation (or victim-centered offender dialogue, as it has come to be known in some circles) builds on Christie's argument that human conflict should be "made visible" and "nurtured" for the potential it may bring to foster community solidarity and interpersonal growth (14).

\section{Family Group Conferencing}

I would never have believed we could resolve this problem so easily - I would have bet it all would have blown up. I was even afraid there would be bloodshed. I'm delighted, but I still can hardly believe it.

- Mother of a student involved in a conference following a racial incident in Minnesota (Nicholl 127)

Variations on family group conferencing models are growing in popularity as a restorative justice practice in some parts of the U.S. and Canada, following what has been standard practice for some time in Australia 
and New Zealand (though recently this practice has come under criticism in those countries ${ }^{1}$ ).

Family group conferencing began in New Zealand on the heels of the 1989 legislation The Children, Young Persons, and Their Families Act. Years of frustration with a criminal justice system that had failed to curb recidivism and that was said to encourage dependency on welfare, provoked 15 years' worth of debate. Since 1989, all young offenders, except in the case of rape or homicide, have been dealt with by conference (129).

Conferencing was introduced after the indigenous Mäori people put pressure on the criminal justice system because they resented having their young offenders removed from their traditional communities. A fundamental Mäori value is that "we are all part of one another and the main purpose of justice is healing for all" ( $\mathrm{J}$. Morris et al 28). The Mäori wanted the New Zealand justice system to adopt their way of handling conflict. For the Mäori, the main purpose of justice is that everyone is healed (33).

The basic elements of family group conferencing are simple. Once offender(s) admit their guilt and have been declared so at a pre-sentencing hearing, victims, offenders, their supporters (friends and family), and members of the community are given an opportunity to meet in the presence of a conferencing facilitator. Participants are encouraged to discuss the direct or indirect effects of the crime on them, each in their own perspective (assuming that the impact on the victim may be a different story than the impact on the 
victim's family). Once the harm is identified and agreed upon by all, a resolution is negotiated and agreed upon by all for repairing the damage and making a plan to correct the offender's behavior (Nicholl 128).

A successful conferencing results in a plan to re-accept the offender back into the community, however all participants define their community. The level of responsibility by the community for the well-being of the offender is more highly focused in the group conferencing model than in any other restorative justice model I studied. The guilt or "whakamä" felt by the offender is recognized as part of their punishment, since it involves lowered selfesteem, depression and withdrawal from social interaction. In very mild cases the person afflicted with whakamä may come out of it on their own, but in most cases it is assumed that they will need the help of others (Metge 94-98).

In practice, a big part of this process is for offenders to make amends with the victims. Offenders are encouraged to demonstrate active responsibility by making reparations, sharing remorse, and apologizing. More creative solutions have transpired. "In one amazing case, a female victim who had been robbed at gunpoint had the offender live in her home as part of

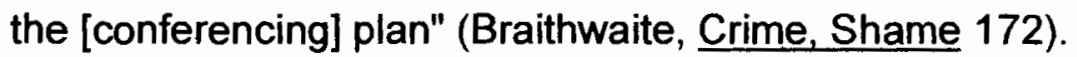

Reintegrative shaming is often a component of family group conferencing, sometimes overtly but more often not. Following up on his own question: Why do most of us not commit crime and comply with rules and procedures?, Braithwaite looked at the Japanese response to crime, where 
the shaming dimension of their culture plays a significant role (Japan has the lowest crime rates of any industrial nation). Braithwaite found that when wrongdoers in Japanese culture are confronted within a context of supporting relationships, a process of "reintegration" can begin. The confrontation by people who are significant to the wrongdoer creates a "shaming experience" that separates the unacceptable behavior from the person. Overtly, this involves the community and conference participants denouncing the unacceptable behavior, but equally voices the need to re-accept the individual back into the community (173).

However, the public has voiced concern (if not outright dissent) about some actions that are being performed under the umbrella of "reintegrative shaming practices" in the U.S. For example, a Texas judge had incorporated shaming into his sentencing decisions, and in one case an offender was required to wear T-shirts with the words, "I am a sex offender" on the front, for life (98). In another case, an offender was made to apologize to his victim of domestic abuse on the steps of city hall, even though the victim did not want to be there. In Rehoboth, Delaware, local police are putting the photos and name of offenders who commit public nuisances in the local newspaper, hoping to shame them (175).

The focus on apologies elicited during conferences has been an issue of contention with restorative justice critics, as apologies are often perceived to be insincere and a product of the conferencing rather than a true expression of 
remorse. ${ }^{1}$ In addition, critics of this practice with the Mäori say that New Zealand's enthusiastic acceptance of this approach

...signifies the indigenization of New Zealand's criminal justice system rather than the empowerment of Mäori... [R]ather than signifying the ability of our justice system to culturally sensitize itself, family group conferencing in fact underlines the willingness of the State to disempower Mäori by employing their justice processes while denying them a significant measure of jurisdictional autonomy (Tauri).

Proponents of group conferencing say the practice also shares many elements of community policing: community involvement, shared ownership and responsibility, collaborative problem solving, identifying ongoing issues of concern, and looking for long term resolution (Nicholl 127). The conferencing model thereby expands policing beyond working at a distance from the community in relation to crime, to a broader approach involving consultation and enlisting the participation of others to resolve crime. As a result, "the police adopt a strong harmonious relationship with anyone who might be able to help in addressing the crime" (153). However, the possible repercussions of having neighbors police neighbors has not been addressed.

In the U.S. and Canada, family group conferencing is gaining recognition. Vermont, Oregon, Maine, Minnesota, Pennsylvania, Georgia, California, and Indiana have either pilot or established conferencing programs (130). What sets conferencing apart from victim-offender mediation and reconciliation programs is its potential for responding collectively to crime and 
to social problems. In that respect, it is perhaps the most suitable candidate for handling hate crimes. (127)

\section{Sentencing and Healing Circles}

The two main types of circles are sentencing circles and healing circles.

The concept of circle sentencing evolved in Canada, initially as an alternative to traditional sentencing of indigenous offenders (Pollard 13). Circle sentencing is a community-based sentencing process administered by members of the community, law enforcement, and members of community support services. A sentencing circle can be held in a court house or a community space (Thomas). Participants include the offender and the victim and their supporters; a judge, a community elder, prosecutor, defense counsel, police and court workers; who sit arranged in an inner circle; and friends and relatives of the offender and the victim, professionals such as alcohol and drug treatment workers and members of the local community; who sit in an outer circle (Linker 117).

While procedures vary from community to community, generally the judge or community elder formally opens the sentencing circle, then each participant introduces themselves and explains why they are attending. The prosecutor outlines the facts of the offense, and the defense counsel responds. Then all participants address the offender and the victim and discuss the extent of similar crimes in their community, the underlying reasons 
for it, the impact on victims and on the community, what must be done to heal the victim and rehabilitate the offender, and what the community can do to prevent similar crimes (Linker; Pollard). Participants develop a sentence plan which the judge uses to sentence the offender. Custodial sentences can be included in a sentence plan; but this is rare (Linker 118).

The sentencing circle reunites several months later to examine the offender's progress towards completing the sentencing plan. If their progress has not been satisfactory, participants can agree to modify or extend the sentence plan, or abandon it. In this case the offender is sentenced by a traditional court (120).

Proponents of circle sentencing argue that it enables participants to contribute directly to the sentencing process, and provides much more information about the offender, the impact of the offense, and problems experienced in the community, than the traditional system can provide (123).

Critics argue that it costs much more than traditional court sentencing processes because it takes longer and uses up more court and community resources (125). It is also criticized on the basis that it gives communities an unstructured discretion in dealing with offenders, leading to inconsistent sentencing outcomes, and that sentence plans may end up being too lenient or too harsh for the offense committed, depending on the attitudes of participants. (Roberts and LaPrairie). On the other hand, it is arguable that closely examining the circumstances of individual offenders and communities 
facilitates responsive sentencing which increases the prospects of rehabilitating offenders (Linker 128).

Circle sentencing is increasingly being used to sentence both indigenous and non-indigenous offenders in the U.S., Canada, Europe, Singapore and New Zealand. Parts of Australia and Queensland have also experimented with circle sentencing (Pollard).

Healing (or peacemaking, or community) circles are held for either the victim (including in cases where no offender has been caught) or for the offender, and are conducted privately with those selected to share decisions about what needs to be done and how the offender will change his or her behavior (Pranis). Like conferencing, there is more emphasis (than with victimoffender mediation) on developing a consensus on social and personal problems surrounding crime. The goal of the healing circle process is to build agreements on needs, hopes, and the means for their fulfillment. Participation is voluntary, and everyone who attends has an equal voice. "The emphasis is on interdependence and connectedness between people and on promoting healthy connections that improve the well-being of those involved" (Nicholl 156).

Like so many other restorative justice practices, healing circles originated in aboriginal communities. McCaslin describes a healing circle that took place in 1994 the Innu community of Sheshashit in Newfoundland, following a sexual assault on a woman in the community: 
The [10] participants had coffee and tea prior to the circle starting. Then all participants moved into the large meeting room and sat in a circle on the floor. With joined hands a prayer was shared. Jack then explained to the participants the symbolism of burning sweetgrass and smudging. If participants found it meaningful they were invited to smudge and Jack went around the circle. He spoke Innuaimen first and then in English...It was explained to participants that what happened in the circle should be guided by the participants' acceptance and use of four principles: honesty, kindness, sharing and respect. Each person in turn would have the chance to speak uninterrupted. If they chose not to speak, they would pass the small "talking stone" on to the next person because no one would be forced to speak. There were four rounds of the circle so there were four opportunities for speaking. The first round of the circle was for each participant to explain why they were present in the circle. The second round was a chance for each participant to speak directly to L., to share concern, support and encouragement. The third round was for each participant to speak directly to Gavin, to share with him directly feelings about him. The fourth round was the chance for each participant to make recommendations to those in the circle, and especially to Gavin, about what could or should be done at this point in time to help bring about resolution to this situation. (McCaslin)

In this example we see that what may distinguish a healing circle from a sentencing circle is the use of traditional rituals and acts of community solidarity. This is perhaps the one distinguishing feature that is most prominent, but there is also the feature of informality (beyond the established rituals) that is not so present in the sentencing circle model.

\section{Notes}

${ }^{1}$ As was noted in the previous section on restorative justice principles, studies in other parts of the world are critical of some aspects of group conferencing, finding that components such as offender apologies and restitution did not adequately satisfy victims' expectations of the process. See Venables, 2001. 


\section{CHAPTER ELEVEN}

\section{Findings}

The fifth step in Comstock's model of critical research in the social sciences calls for elucidation of the "fundamental contradictions" which have developed due to "actions based on ideologically frozen understandings" (Comstock). This analysis will follow the subset of steps suggested for this process:

-- Compare conditions with understandings;

-- Critique the Ideology; and

-- Discover imminent possibilities for action.

\section{Conditions vs. Understandings}

One of the first interesting contradictions I found was actually in the form of an irony. In Allport's The Nature of Prejudice, the description of a "fanatic" has characteristics in common with the "integrated" individual who is thought to have gained control of his or her prejudicial nature. "It is the rigid consistency of the fanatic (whether of a bigot or a crusader for equal rights) that is regarded as pathological in our society" (337). At the same time, Those who want integration wish to face their prejudices and ethics and put them all 
"under the dominance of a wholly consistent philosophy of human

relationships. This striving for wholeness and maturity requires a consistency that is extremely hard to achieve" (338). The contradiction here is that in order to overcome one's prejudicial nature, it seems that one must strive for a consistency of thought and action that at some point can be regarded by some as fanaticism - which is the mark of the extremist! As it turns out, this irony appears to play out in the rhetoric of the two fields, with each side claiming the other side to be fanatics of sorts (e.g. "right-wingers," "Zionists," "hawks," "doves," etc.), and may be implicated in what becomes "ideologically frozen understandings" (Comstock) in both fields. This contradiction is apparent in the compromise solutions cited by Allport: "An outstanding fact of social life is that the multiplicity of roles a man has to play forces him into inconsistent behavior" (337). The process of striving for integration while at the same time avoiding fanaticism can only lead to instances of inconsistent behavior that at the very least slow down the momentum of any social movement. What also appears to happen as a way to survive this inner struggle is that adherents of one movement will insulate themselves from other movements, in order to maintain equilibrium. Examples include the reluctance of white upper middle class adherents of the women's liberation movement of the 1960s to take on the agendas of discrimination against lesbians or African-American women, for fear the movement would not be taken seriously. "Part of the overwhelming frustration black women felt within the Women's Movement was at white 
feminists' unwillingness to admit to their racism. This unwillingness comes from the sentiment that those who are oppressed cannot oppress others" (Thistle). This denial of one's personal prejudice while struggling to eliminate prejudice in social contexts fulfills three of Allport's four modes (334) of "contrary impulses" : repression, defensive rationalizations, and compromise solutions. But the fourth mode - "integration" - is problematic. Ironically, the contradiction of definitions of "consistency" in describing fanatics and tolerant "integrated individuals" shows how fundamentally related in conviction may be the liberals and the conservatives.

The people who are studying hate crime as a social issue and restorative justice as a prescription have in common the problem of "fuzziness" of definitions. I once asked a police officer "What is a hate crime?" and she said, "I can't always define it very well but I know it when I see it." I asked a victim-offender mediator "What is restorative justice?" and he said, "I can't always define it exactly, but I know it when I do it." Fuzziness is this state of "knowing it" intuitively but not being able to adequately define it. A movement or practice can fossilize if its intent can never be adequately defined. It is clear that the public is divided on what constitutes a "hate crime," but it is also clear that the hate crime activists are equally divided. Likewise, those researching the theories and practices of restorative justice do not agree on what constitutes a restorative justice "action" versus any other kind of prescriptive action beyond the ambiguously retributive. In addition, there 
appears to exist separate sets of definitions of restorative justice - one set defines it in terms of principle, while another set defines it in terms of practice.

This sort of fuzzy status of definitions leads to a related problem: "bandwagon syndrome." This is a metaphor for the problem of every sort of crime eventually being defined as a "hate crime" (along the lines of how, since September 11 , every violent or threatening act by a politically motivated group has been re-defined as "terrorism") and every "feel-good" action in any justicerelated movement being lumped into the category of "restorative justice." The "bandwagon syndrome" in the hate crime movement is a way of saying "everybody on board who has ever been a hate crime victiml" Since the hate crime definition is constantly being changed by political rhetoric, eventually so many people "climb on board" that there is nothing distinct enough about the definition to make it viable. I have read accounts where a row of SUVs were vandalized on one street and therefore the crime is a "hate crime against SUV owners," and another an anti-fur activist was charged with a "hate crime against capitalists" for smashing a fur store window. ${ }^{1}$

Likewise, in the restorative justice movement, there is a propensity for "all good things" to be claimed as restorative justice actions while "all bad things" are claimed to be retributive. This propensity not only goes for "things" that happen along the way, but "things" that happened in the long ago. "The idea of restorative justice has become so popular, the term is now applied after the fact to programs and policies that have been in place for some time, 
or it is used to describe reputedly new policing and correctional policies" (Daly, $\underline{\mathrm{RJ}}$ in Diverse Societies). ${ }^{2}$ I personally became aware of restorative justice "bandwagon syndrome" when, after explaining a few concepts of restorative justice to a professor, she said, "I've never heard of restorative justice, but from what you're telling me, it must have come from feminist theory." Though it can be said that all justice movements have in common some principles and theories, it may be more useful to make clear the distinctions rather than the similarities while a new movement is trying to find its momentum among the plethora of social causes that individuals are daily encouraged to care about.

\section{Critique of Ideology}

The final contradiction I see in both of these issues as they play out in contemporary times is that the ideological rhetorics tend to steer clear of issues of class and economics in favor of a focus on character and principle. In other words, prejudice is presented as important because of its status as a character flaw, and upholding restorative justice principles is presented as important because it is "taking the higher ground." If we view prejudice as simply a character flaw, we don't have to pay any attention to what societal strains may be implicated in what eventually results in hate crime; we can just focus on treatments for character flaws. If we view restorative justice as being worthwhile simply on the basis that it is "taking the higher ground," we don't 
have to pay so much attention to what economic or power structure changes may be needed to reduce crime.

John Braithwaite, in his keynote address at the first North American Conference on Conferencing, said that "restorative justice will never become a mainstream alternative to retributive justice unless long-term $R$ [esearch] and $D[$ evelopment] programs show that it does have the capacity to reduce crime" (Braithwaite qtd. in Wachtel). ${ }^{3}$ We may have "evidence" that victims, offenders, and restorative justice practitioners find restorative justice actions to be principled and just, but we have not adequately demonstrated that any restorative justice action significantly reduces or prevents crime. Though there have been several studies conducted to measure rates of youth offender recidivism, these studies have not factored in other crucial variables at the time they participate in a restorative justice action. This is important because it may be shown that offender recidivism is often reduced, with or without any restorative justice action, by other factors. Also, there has been no study that follows offenders when and if they move out of the jurisdictional areas in which the recidivism statistics are gathered.

Restorative justice practitioners claim that recidivism is not the best indicator for success of an action, and that "empowerment" of the participants is a more important outcome. However, research has shed scant light on what "empowerment" means or how to measure it, in order to make the claim that a restorative justice action will help one to feel "empowered." In fact, recent 
follow-up research on victims who underwent restorative justice actions has shown that victims sometimes feel no less "empowered" than they did before the action, and sometimes feel less empowered (Daly, The Real Story; Venables).

Likewise, we may have adequately proven that hatred is a bad thing and people shouldn't have it, but we have not proven that upholding the viability of the "hate crime" category in our systems of justice will reduce the conditions that lead to the hate that leads to the crime. Jay MacLeod, in his book Ain't No Makin' It asserts that as long as "social problems are reduced to problems of individual morality and pathology in contemporary American politics, there is no critique of the class structure..." (267). As long as inequities in the social hierarchy are discussed solely in terms of racial and ethnic intolerance, the issue of poverty remains a discussion solely for "the ethnic community." Whites living in poverty or who are undergoing traumatic displacement of other types are excluded from this conversation. In any case, it is white upper- and middle-class citizens that should be accountable for the discussion of resolutions.

As indicated by Blazak's initial inquiry into strain theory (Blazak, Ethnographic study) as a basis for defining the problem of hate-motivated violence, no matter how much a justice practice can claim "higher ground" in principle, it will tend to reproduce existing relations of inequality (Daly, $\underline{R J}$ in Diverse Societies 182). It may take social restructuring that redistributes 
wealth and changes divisions of labor and power before we will see reductions in crime of any kind, but particularly of crime that is motivated by awareness of deeply-rooted inequities.

Perry found that hate crime offenders may be using hate crime as a way to forge "relational identities" in society (Perry 52). "The structures of oppression and their supporting institutional patterns provide the context and constraints within which we 'do difference' in as human actors" (53). When there appears to be so few "niches" left in which to clearly differentiate oneself from all others in terms of identity, some may choose identification with an extremist movement as a reflection of how few choices of identity they see for themselves. This has little to do with "hate," per say, and much to do with the strain of societal inequities that are never addressed in that context.

\section{Possibilities for Action}

So far this paper has shown that the sought-after congruencies connecting hate crimes research with restorative justice principles have mostly to do with shared contradictions in principle and action. There is one shining example of how a typical restorative justice action (victim-offender mediation) played out in the case of a hate crime, when skinheads vandalized a synagogue and, after being charged in court, agreed to meet with the rabbi and other synagogue members for a mediation in order to hear out the victims on the harm done by their crime (Lerman). It was discovered during the 
mediation that what primarily motivated the offenders was not a principled hatred of Jews, but the strain of feeling like outcasts of society: they were runaways, poor and displaced, and had been bouncing through foster homes. "They had been inculcated into neo-nazi thought as just 'something to do,' without really understanding what it meant" (1). ${ }^{4}$

This scenario has been repeated in my own personal experience as a mediator and in working with hate crime offenders and former offenders. One former skinhead, speaking as part of a presentation for which I was also a speaker, ${ }^{5}$ tells groups nationwide about his experience getting into the skinhead movement, and for basically the same reasons: feeling displaced and unwanted, from a broken family, and bouncing through foster homes. He also explains that he was able to leave the skinhead movement because a perceptive foster mother, a psychologist, found how to reach him:

She talked to me. Every day. About everything - how was I doing, what did I need, stuff like that -- but never a word about the nazi tattoos on my arms or the swastikas on my bedroom wall. She just asked me how I was, what did I need, over and over, making sure I was taken care of and felt safe. She always made sure I had everything I needed -- food, clothes, bus money. She always had stuff for me to do around the house and the yard, so that I had a reason to be home. Eventually, over time, I found I didn't need to go to [skinhead meetings] to feel good about myself. I felt good just going home and hanging out. ${ }^{5}$

What seems to work here is not that the racist is convinced his or her racism is a bad thing he or she should be cured of, but that racism is but a symptom of some greater ill -- traumatic displacement; feeling unwanted and 
unimportant, being denigrated to a lower status of identity. In this particular case, the elevation of status from consistently "unimportant" to consistently "important" seems to have played a major role in the rehabilitation of the offender, especially since the racism was never addressed.

There is evidence outside of the restorative justice field that appear to have some hope for pinpointing the basic inequities fueling xenophobia. Several youth programs across the country have focused on the issue of youth hate crime by putting offenders through a rigorous program of psychological evaluation and therapy, multi-hour educational programs, and community service (Malloy). Looking through summaries of all the programs, the overwhelming congruency is that efforts are made to relieve social inequities being experienced by the offenders. "Offenders are placed in professional settings in the community, not homeless shelters or HIV clinics, to defeat stereotypes they may have of certain groups and to increase their awareness of the inherent value of diversity" is a feature of the Juvenile Diversion Project sponsored by the Anti-Defamation League in New York City. Though the goal is to get the offenders to see how they have stereotyped others, it may also have the added value of bringing offenders into interactive social contexts they may have thought of as off-limits to them by virtue of their class or economic status. All the programs rely heavily on creative community service work (e.g. not just picking up trash on the freeway), which also may have similar effects. 
An experiment in inter-group behavior carried out by Muzafer Sherif and his colleagues was discussed earlier in this paper (see "Hate Crime Causes" in this thesis). Sherif randomly assigned 12 -year-old boys to two groups at a Boy Scout camp. Within each group the boys were taught to cooperate. After they were all getting along very well with members of their particular group, Sherif set up a series of competitive activities to pit each group against each other, with prizes awarded to the winning group. There were also situations set up to disrupt the balance of fairness in the distribution of food. As predicted, these conflicts and disruptions resulted in name-calling and food-throwing between members of each group, "and within a very short time a full-scale riot was in progress" (Aronson qtd. in Baird 131). Then Sherif eliminated the staged conflicts and initiated non-competitive social contact between the boys. But to the surprise of all, this did not end the hostilities...in fact, hostilities escalated, even when the boys were engaged in benign activities like sitting around watching TV (131).

What finally brought these boys back to their original state of getting along? The key appeared to be the creation of a task that required interdependence in order to elicit empathy. Sherif arranged for a vehicle to get stuck in the mud, and when the boys found that the only way to get unstuck was to cooperate in solving the problem, the act of cooperation spurred them to reunite as one group and hostilities vanished thereafter (132). Sherif asserts that the activity generated empathy because every boy was needed equally for 
the task to be successful, and each, by experience, knew how difficult the task was for all. This had the effect of putting all the boys on the same level. There were no inequities. And their former mutual hate was never addressed.

Notes

${ }^{1}$ I read about the SUV case at Denverchannel.com, and the fur store case at LibertySearch.com, both on the WWW.

2 Daly cites Carol La Prairie (1999), "Some reflections on new criminal justice policies in Canada: restorative justice, alternative measures and conditional sentences," Australian and New Zealand Journal of Criminology 32(2): 139-52; and Adam Crawford (2001), "The prospects for restorative youth justice in England and Wales: a tale of two acts," in K. McEvoy and T. Newburn (eds.) Criminology and Conflict Resolution, London: Macmillan.

3 John Braithwaite's address was titled "Linking Crime Prevention to Restorative Justice," presented at the First North American Conference on Conferencing, Minneapolis, Minnesota, August 6-8, 1998.

${ }^{4}$ The parties agreed that the offenders would spend some time with the rabbi and the synagogue members learning more about Jewish traditions and fixing the damage done by the vandalism. I did not find any documented follow-up to this action for an analysis on how the action may have affected the offenders over time.

${ }^{5}$ The presentation, "Healing Hate: Responding to Hate Crimes Restoratively," took place in at the 2001 VOMA Conference in Portland, Oregon. My co-presenters were Steve Stroud, former skinhead and co-director of Oregon Spotlight, an organization that helps youths leave extremist movements; and Norm Costa, a Portland activist on behalf of the GLBT community. 


\section{CHAPTER TWELVE}

\section{Conclusion}

I grew up believing that I was safe. Most people in my white, middleclass, North American world did not get shot at. Even adding the fact of my being a lesbian in no way prepared me for murder. Lesbians I knew got called names--an aggravating, uncomfortable, infuriating experience but not generally dangerous. I grew up as a Jew, knowing that my father had fled from Austria because of the Holocaust. That kind of lifeendangering oppression was history to me, or something that happened to other people, with other skin colors or names different from mine (Brenner 159).

Hate crime is a symptom of a deeply-rooted societal problem that is based on economic and power inequities. This is perhaps the most important "deeper issue" I found from researching and writing my thesis, and which is primarily responsible for those uncomfortable feelings I had before I started my research. I agree with Jack Levin when he says that hate "originates not in the ranting and raving of bigoted extremists at the margins of society but in the tacit approval of the ordinary, even decent, people who are located squarely in the mainstream" (J. Levin, Violence of Hate). The biggest (and hardest) lesson I learned from this review is that you can fool yourself into believing you are doing your part to make a better world, but what you might really be doing is helping to cover up the real problems. 
Claudia Brenner and Rebecca Wight were hate crime victims, but that is not all that they were. They were also both from well-to-do families and they were college students on the track toward lucrative vocations in the fields of engineering and architecture. Brenner is currently an architect in upstate New York. She endured a horrible crime that no one should have to go through, but it was inevitable that after such an event she would receive the best of care in her long recovery process. She was able to heal successfully and be a better for it because she had the benefit of a marvelous support system in place before she experienced her tragedy, and which made it possible for her to enter back into her community successfully and gracefully. But I wonder what would have transpired if the two lesbians making love that day were actually homeless immigrants who had fled a war-torn country and were living in the park for lack of any other place to go. What story would I have read about them? If a similar fate had ever fallen upon the shooter, who was terminally homeless and had an IQ of about 70, would there be such a support system readied for him? The victims and the offender in this case really do come from different worlds, despite the fact that on the surface the claim can be made they are all members of categorical minorities. It is easy to make the issue of hatred toward racial or sexual minorities as being "the problem," but is xenophobia the only reason for hate crimes? The idea that the victims and offender in this case are "members of the same community" that could find 
some point of authentic reconciliation is perhaps oversimplifying the underlying problems. Perhaps it will make the work of healers valid and empowering, but it does not solve the very real issues of poverty and oppression that will remain long after the healing rituals are over.

I found that even the legal and social complications in the hate crime issue were often smoke screens that made it possible to not deal with the real problem of why hate crimes happen: it's not only because we don't have the laws down right, or don't have the "right" kind of justice system, it's because we keep focusing on changing our justice procedures instead of changing the societal conditions that create the oppression that motivates crime. We keep talking about how "senseless" hate crimes are, but we don't get the message about how warped of a reality a person can find themselves in that makes such crimes seem liberating. We can make laws or new procedures till the cows come home, but it won't stop people from hating their lives so much that it actually relieves some of the strain to take it out on other people.

I began this thesis with the hope that restorative justice could offer some solace in the complex harm created by hate crime. It certainly made me feel good to practice it in my own life. I believe it can help in some cases, but my experience so far has been that it is set up for and is mostly helping members of the dominant culture, whether they be victims or offenders or both. Until restorative justice practitioners get a handle on the deeper issues - 
the reasons for injustice -- they can only do what is already being done: cover up the real problems by allowing people to feel like they are doing the right thing without really doing much at all. The fact of the matter is that solving the cause of hate crime is going to be very difficult, and it probably means that people like Claudia Brenner and you and me will have to make some sacrifices and step out of comfort zones we have surrounded ourselves in.

We'll have to start reframing some of our issues, such as reframing "How are we going to rid the world of terrorists?" into "What is going wrong for these people that they are so desperate to get our attention?" We'll have to listen to what the racists are telling us between the lines -- like Steve Stroud's foster mom listened to him, unconditionally -- and hear about what the world looks like when you have reached the end of your rope and everyone else is the enemy. We'll have to stop taking credit for solutions that came without our help, like the moments of clarity experienced by former leaders of extremist movements. Sometimes it takes getting into extremely unpopular positions to see the light -- how can we help that happen without tripping all over our own principles? Perhaps we need to look more deeply at the essence of conflict to see what rewards it has in store for us, what we're missing by trying to kill it with kindness.

This thesis has been a productive learning experience for me, though I certainly did not reach the conclusion I thought I would when I started. It is 
perhaps the best thing that could have happened, because now I see those "deeper issues" of societal strain based on economics and power that are often shielded by other rhetoric. I feel like I can act on the real issues now, instead of wasting time on simply trying to make myself feel like I'm doing the right thing. This is my moment of clarity. 


\section{BIBLIOGRAPHY}

\section{Hate Crimes}

Aho, James A. The politics of righteousness: Idaho Christian patriotism.

Seattle: University of Washington Press, 1990.

Allport, Gordon W. The Nature of Prejudice. 1954. Cambridge, Mass: Perseus Books, 1979.

American Psychological Association (APA). Hate Crimes Today: An Age-Old

Foe in Modern Dress. Position Paper, 1998. 16 Oct. 2001

<http://www.lambda.org/apa_hate.pdf >.

Aronson, Elliot. "Causes of Prejudice." Hatred, Bigotry, and Prejudice:

Definitions, Causes and Solutions. Eds. Baird, Robert M. \& Stuart E.

Rosenbaum. Amherst, NY: Prometheus Books, 1999: 127-140.

Baird, Robert M. "R.A.V. Petitioner v. City of St. Paul, Minnesota." Hatred, Bigotry, and Prejudice: Definitions, Causes \& Solutions. Eds. Robert M. Baird \& Stuart E. Rosenbaum. Amherst, NY: Prometheus Books, 1999: 63.

Bensinger, Gad. "Hate Crimes: A New/Old Problem." International Journal of Comparative and Applied Criminal Justice 16 (1992): 115-123.

Blazak, Randy. "White Boys to Terrorist Men: Target Recruitment of Nazi Skinheads." American Behavior Scientist 6 (2001): 982-1000.

-.- The suburbanization of hate: An ethnographic study of the skinhead subculture. Diss. Emory University, 1995. DAI-A 56/10 (1996): 4167.

Blee, Kathleen. Inside Organized Racism. Berkeley: Univ. of California Press, 2002.

-- Women of the Klan: Racism and Gender in the 1920s. Berkeley: University of California Press, 1991.

Boswell, John. Christianity, Social Tolerance, and Homosexuality. Chicago: University of Chicago Press, 1980. 
Bowling, Benjamin. "Racial harassment in east London." Hate crime: International perspectives on causes and control. Ed. Mark S. Hamm. Cincinnati, OH: ACJSIAnderson, 1994: 1-36.

Brenner, Claudia with Hannah Ashley. Eight Bullets: One Woman's Story of Surviving Anti-Gay Violence. Ithaca, NY: Firebrand Books, 1995.

"But Some of Us Are Brave: A History of Black Feminism in the United States." The Thistle 9.1 (1995). Mass. Institute of Technology. 10 Jan. 2002. <http://www.mit.edu:8001/activities/thistle/>.

Copeland, Lois and Leslie Wolfe. Violence Against Women as Bias Motivated Hate Crime: Defining the Issues. Washington, DC: Center for Women Policy Studies, 1991.

Ellis, William W. Bias crime. Washington, DC: National Research Council, 1990: $2-4$.

Ehrlich, Howard J. and R. Purvis, B. Larcom, \& P. Webbink. "Traumatic Impact of Ethnoviolence." The Price We Pay: The Case Against Racist Speech, Hate Propaganda, and Pornography. Eds. Laura J. Lederer and Richard Delgado. Towson, MD: The Prejudice Institute, Center for the Applied Study of Ethnoviolence, 1995. 63-76.

Ezekiel, Raphael S. The Racist Mind: Portraits of American Neo-Nazis and Klansmen. New York: Viking, 1995.

Ferber, Abby. White Man Falling : Race, Gender, and White Supremacy. Lantham, MD: Rowan \& Littlefield, 1998.

Finn, Peter and Taylor McNeil. "Bias Crime and the Criminal Justice Response." A Summary Report Prepared for the National Criminal Justice Association. Cambridge, MA: Abt Associates, 1988.

Finn, Peter. "Bias Crime: Difficult to Define, Difficult to Prosecute." Criminal Justice 2 (1988): 18-23.

Friedman, Lawrence. Crime and Punishment in American History. New York: Basic Books, 1993.

Garnets, Linda, Gregory M. Herek \& Barrie Levy. "Violence and victimization of lesbians and gay men: Mental health consequences." Journal of Interpersonal Violence, 5 (1990): 366-383. 
Grattet, Ryken, Valerie Jenness, and Theodore R. Curry. " The Homogenization and Differentiation of Hate Crime Law in the United States, 1978 to 1995: Innovation and Diffusion in the Criminalization of Bigotry." American Sociological Review 63.2 (1998): 286-307.

Hamm, Mark S. "Terrorism, Hate Crime, and Antigovernment Violence." The Future of Terrorism: Violence in the New Millennium. Ed. Harvey $W$. Kushner. Thousand Oaks, CA: Sage Publications, 1998: 55-96.

--. "Conceptualizing hate crime in a global context." Ed. Mark S. Hamm Hate crime: International perspectives on causes and control. Cincinnati, OH: ACJS/Anderson, 1994: 173-194.

--- American Skinheads: The criminology and control of hate crime. New York: Praeger, 1993.

Hasselbach, Ingo. Fuhrer-Ex : Memoirs of a Former Neo-Nazi. New York, NY: Random House, 1996.

Herek, Gregory M. and Berrill, Kevin T., eds. Hate Crimes: Confronting Violence Against Lesbians and Gay Men. Newbury Park, CA: Sage Publications, 1992.

Herek, Gregory. M., J. Roy Gillis, \& Jeanine C. Cogan. "Psychological sequelae of hate crime victimization among lesbian, gay, and bisexual adults." Journal of Consulting and Clinical Psychology 67 (1999): 945-951.

Hernández, Tanya.K. "Bias Crimes: Unconscious Racism in the Prosecution of Racially Motivated Violence." Yale Law Journal 99, (1990): 832-64.

Jacobs, James B. \& Kimberly Potter. Hate Crimes: Criminal Law \& Identity Politics. New York: Oxford, 1998.

Jacobs, James. B. "Should Hate be a Crime?" The Public Interest 113 (1993): 3-14.

Jenness, Valerie and Ryken Grattet. Bias Crime Politics and Public Policy: Building a Response to Discriminatory Violence. American Sociological Association's Rose Series in Sociology. New York: Russell Sage Foundation, 2000. 
Jost, Kenneth. "Hate Crime and Free Speech: an Overview." Hate Crimes. Ed.

Paul Winters et al. Current Controversies Ser. San Diego, CA:

Greenhaven Press, 1996: 57-59.

Katz, Jack. Gay American History: Lesbians and Gay Men in the U.S.A. New York: Thomas Y. Crowell Company, 1976.

Kleg, Milton. Hate, Prejudice and Racism. Albany, NY: State of New York Press, 1993.

Kressel, Neil K. Mass Hate: The Global Rise of Genocide and Terror. New York: Plenum Press, 1996.

Levin, Brian. "Hate Crimes: Worse by Definition." Journal of Contemporary Criminal Justice, 15.1 (1999): 6-21.

---. "A Dream Deferred: the Social and Legal Implications of Hate Crimes in the 1990s." The Journal of Intergroup Relations 3 (1993): 327.

Levin, Jack. The Violence of Hate: Confronting Racism, Anti-Semitism, and Other Forms of Bigotry. Boston, Mass.: Allyn \& Bacon, 2002: v)

--. The Functions of Prejudice. New York: Harper \& Row, 1975.

Levin, Jack \& Jack McDevitt. Hate Crimes: The Rising Tide of Bigotry and Bloodshed. New York: Plenum Press, 1993.

Lutz, Chris. They Don't All Wear Sheets: A Chronology of Racist and Far Right Violence: 1980-1986. Atlanta, Georgia: Center for Democratic Renewal, 1987.

Mallow, Stephanie M. "Best Practices in Juvenile Hate Crime Rehabilitation." Reviving Hope in the Face of Hate: A Guide for Countering Juvenile Hate Crime. National Center for Hate Crime Prevention. 10 April 2001. $<$ http://www.edc.org/HHD/hatecrime/id7_m.htm>.

McLeod, Jay. Ain't No Makin' It: Aspirations and Attainment in a Low-Income Neighborhood. Boulder, CO: Westview Press, 1995.

Monroy, Emily. "White Guilt." Interracial Voice, Sept-Oct. 2000. 24 Feb. 2001. <http://www.webcom.com/intvoice/emily7.html>. 
Newton, Michael and Judy Ann Newton. Racial and Religious Violence in American: A Chronology. New York: Garland Publishers, 1991.

Ogawa, Brian. Color of Justice: Culturally Sensitive Treatment of Minority Crime Victims. Sacramento, CA: Office of the Governor, State of California, 1990.

Perry, Barbara. In the Name of Hate: Understanding Hate Crimes. New York: Routledge, 2001.

Smith, B. L. Terrorism in America: Pipe bombs and pipe dreams. Albany: State University of New York Press, 1994.

Stinski, Brent F. "Enhanced Penalties for Hate Crimes: an Overview." Hate Crimes. Ed. Paul Winters et al. Current Controversies Ser. San Diego, CA: Greenhaven Press, 1996: 108-113.

UCR. Uniform Crime Reports: Hate Crime Reporting Statistics. Washington, DC: Federal Bureau of Investigation, 1999.

Witte, Robert. "Comparing state responses to racist violence in Europe: A model for international comparative analysis." Hate crime: International perspectives on causes and control. Ed. Mark. S. Hamm, Cincinnati, $\mathrm{OH}$ : ACJS/Anderson, 1994: 91-104.

Wooden, Wayne S. \& Randy Blazak. Renegade Kids, Suburban Outlaws: From Youth Culture to Delinquency. 2nd Ed. Wadsworth Contemporary Issues in Crime and Justice Ser. Belmont, CA: Wadsworth, 2001.

Young, Marlene A. "Serving Victims of Bias Crimes." The Road to Victim Justice: Mapping Strategies for Service. Regional Training Conferences Series. National Organization for Victim Assistance and National Victim Center, 1992. 
Restorative Justice

Bazemore, Gordon. '"The Community' in Community Justice: Issues, Themes, and Questions for the Neighborhood Sanctioning Models." Justice System Journal 19 (1997): 193-228.

--. "Three Paradigms for Juvenile Justice." Restorative Justice: International Perspectives. Eds. Burt Galaway \& Joe Hudson. New York: Criminal Justice Press, 1996: 37-67.

Bianchi, Herman. Justice as Sanctuary: Toward a New System of Crime Control. Bloomington: Indiana University Press.1994.

Braithwaite, John. "Restorative Justice: Assessing an Immodest Theory and a Pessimistic Theory." Crime and Justice: An Annual Review of Research: 25. Ed. Michael Tonry. University of Chicago Press, 1999: 4-26.

--.. "Restorative Justice and a Better Future." Dorothy J. Killam Memorial Lecture. Australian National University. Dalhousie University, 17 October, 1996. 4 Apr. 2002.

<http://www.realjustice.org/Pages/braithwaite.html>.

--. Crime, Shame and Reintegration. New York: Cambridge University Press, 1994.

Brogden, Mike. "Law, Order and the Justice Question." Fortnight 372 (1998): 14-15.

Christie, Nils. Limits to Pain. New York: Columbia University Press, 1981.

--. "Conflict as Property." British Journal of Criminology 17 (1978): 1-15.

Clarke, Stevens H. Mediation of Interpersonal Disputes in North Carolina: An Evaluation. Chapel Hill, NC: University of North Carolina,1992.

Daly, Kathleen. "Restorative Justice: the real story." Punishment \& Society 4.1 (2002): 55-79.

---. "Restorative Justice in Diverse and Unequal Societies." Law in Context 17.1 (2000), 166-201. 
Davis, Gwynn. Making Amends: Mediation and Reparation in Criminal Justice. London and New York: Routledge, 1992.

Dzur, Albert W. and Susan M. Olson. "Constructing Community: Restorative Justice in Theory and Practice." Delivered at the Annual Meeting of the American Political Science Association, San Francisco, August 30, 2001. 8 Apr. 2002.

<http://pro.harvard.edu/papers/002/002028DzurAlbert.pdf>.

Eglash, Albert. "Beyond Restitution: Creative Restitution." Restitution in Criminal Justice. Eds. J. Hudson, and B. Galaway. Lexington, MA: Lexington Books, 1975.

Fishkin, James S. The Voice of the People: Public Opinion and

Democracy. New Haven: Yale University Press, 1995.

Foucault, Michel. Discipline and Punish: The Birth of the Modern Prison, Hammondsworth: Penguin, 1977.

Galaway, Burt \& Joe Hudson, eds. "Introduction." Restorative Justice: International Perspectives. New York: Criminal Justice Press, 1996: 1-14.

Habermas, Jurgen. Between Facts and Norms: Contributions to a Discourse Theory of Law and Democracy. Cambridge, MA: MIT Press, 1996.

Haley, John O. "Confessions, Repentance, and Absolution," Mediation and Criminal Justice: Victims, Community, and Offenders. Eds. Martin Wright and Burt Galaway. Newbury Park, CA: Sage Publications, 1989.

Hohri, William M. Repairing America: An Account of the Movement for Japanese -American Redress. Pullman, WA: Washington State University Press, 1988.

Kulchyski, Peter \& Don MCCaskill, David Newhouse. Eds. In the Words of Elders. Toronto: University of Toronto Press, 1999.

LaPrairie, Carol. "Community Justice or Just Communities? Aboriginal Communities in Search of Justice" Canadian Journal of Criminology 37 (1995): 521-545.

Linker, Maureen. "Sentencing Circles and the Dilemma of Difference." Criminal Law Quarterly 42 (1999): 116-128. 
Lerman, David. "Restorative Justice and Jewish Law." VOMA Quarterly, Winter 1998.

Llewellyn, Jennifer J. and Robert Howse. "Restorative Justice: a conceptual framework." Prepared for the Law Commission of Canada, Ottawa, Ontario, 1998. 10 Nov. 2001. <http://www.lcc.gc.ca/>.

Masters, Guy. "Values for Probation, Society and Beyond." The Howard Journal, 36.3 (1997): 237-247.

McCaslin, Wanda (ed). "A Healing Circle in the Innu Community of Sheshashit." Justice as Healing 2.2 (1997). 23 Jan 2002. $<$ http:/hww.usask.ca/nativelaw/jah.html>.

McCold, Paul. "Restorative Justice and the Role of Community." Restorative Justice: International Perspectives. Eds. B. Galaway \& J. Hudson. New York: Criminal Justice Press, 1996: 85-101.

McElrea, Frederick W. M. Bridging the Cultural Divide. Royal Commission on Aboriginal Peoples. Ottawa: Canada Communication Group Publishing, 1996.

Metge, Joan. In and Out of Touch: Whakamä in Cross Cultural Perspective. Wellington: Victoria University Press, 1986.

Monture-Okanee, Patricia A. "Thinking About Aboriginal Justice: Myths and Revolution." Continuing Poundmaker and Riel's Quest. Eds. Richard Gosse, James Youngblood Henderson, and Roger Carter. Saskatoon: Purich Publishing, 1994: 222-232.

-.-. "Reclaiming Justice: Aboriginal Women and Justice Initiatives in the 1990s." Aboriginal Peoples and the Justice System: Report of the National Round Table on Aboriginal Justice Issues. Royal Commission for Aboriginal Peoples. Ottawa: Ministry of Supply and Services Canada, 1993: 105-132.

Morris, Joanne and Margaret Lee, D.F. Dugdale, Denese Henare, and Timothy Brewer (ed). Justice: "The Experiences of Mäori Women." Report 53. The Office of the Law Commission. Wellington, New Zealand: 1999. 23 Mar 2002. <http://www.lawcom.govt.nz/>.

Morris, Ruth. "Transformative Justice Tackles Structural Inequality." Restorative Justice: Four Community Models. Saskatoon, Saskatchewan: MCC Can. Victim Offender Ministries, 1995. 
Nicholl, Caroline G. "Community Policing, Community Justice, and Restorative Justice: Exploring the Links for the Delivery of a Balanced Approach to Public Safety." Washington, DC: U.S. Department of Justice, Office of Community Oriented Policing Services, 1999.

Peachey, Dean. "The Kitchener Experiment." Mediation and Criminal Justice: Victims, Community, and Offenders. Eds. Martin Wright and Burt Galaway. Newbury Park, CA: Sage Publications, 1989.

Pollard, Charles. "Victims and the Criminal Justice System: A New Vision." Criminal Law Review 5 (2000): 13-15.

Pranis, Kay. Building Community Support for Restorative Justice: Principles and Strategies. Minnesota Department of Corrections, 1995. 2 Nov. 2001. < http://members.aol.com/fcadp/archives/Community.htm>

Roberts, Joseph and Carol LaPrairie. "Sentencing Circles: Some Unanswered Questions." Criminal Law Quarterly 39 (1997): 75.

Ross, Rupert. Returning to the Teachings: Exploring Aboriginal Justice. Toronto: Penguin Books, 1996.

Shapland, Joanna, and J. Wilmore and P. Duff. Victims in the Criminal Justice System. Cambridge Studies in Criminology. Gower: Aldershot, 1985.

Sharpe, Susan. Restorative Justice: A Vision for Healing and Change. Edmonton: Edmonton Victim Offender Mediation Society, 1998.

Strong, Karen Heetderks and Dan Van Ness. Restoring Justice. Cincinnati: Anderson Publishing Company, 1997.

Tauri, Juan M. "Family Group Conferencing: The Myth of Indigenous Empowerment in New Zealand." Justice as Healing 2.2 (1997). 23 Jan. 2002. <http://www.usask.ca/nativelaw/jah.html>.

Thomas, Brendan. "Circle Sentencing: Involving Aboriginal Communities in the Sentencing Process." New South Wales, Attorney General's Department, Aboriginal Justice Advisory Committee, 1999. 12 Dec. 2001. <http://www.lawlink.nsw.gov.au/> 
Umbreit, Mark. "Avoiding the marginalization and 'McDonaldization' of victim offender mediation: a case study in moving towards the mainstream." Restorative Juvenile Justice. Eds. G. Bazemore \& L. Walgrave. New York: Criminal Justice Press, 1999.

Van Ness, Daniel W. "Restorative Justice and International Human Rights." Restorative Justice: International Perspectives. Eds. B. Galaway \& J. Hudson. New York: Criminal Justice Press, 1996: 17-35.

Venables, Michele. "Restoration versus Alienation: Family Group

Conferencing from the Perspectives of Victims." Griffith University, Queensland, 2001. 23 Feb. 2002.

<http://www.aic.gov.au/rjustice/venables/>.

von Hirsch, Andrew. "Penal Theories." The Handbook of Crime and

Punishment. Ed. M. Tonry. New York: Oxford University Press, 1998.

von Truensee, Vanessa. "Transcending Retributive Models Of Justice." E Law: Murdoch University Electronic Journal of Law 7.4 (2000). 12 Oct. 2001. $<$ http://www.murdoch.edu.au/elaw/>.

Wachtel, Ted. "Restorative Justice in Everyday Life: Beyond the Formal Ritual." Paper presented at the "Reshaping Australian Institutions Conference: Restorative Justice and Civil Society." The Australian National University, Canberra, February 16-18, 1999. 10 Jan 2002. <http://www.restorativepractices.org/Pages/anu.html>.

Walgrave, Lode. "Restorative Justice for Juveniles: Just a Technique or a Fully Fledged Alternative?" The Howard Journal, , 34.3 (1995): 228-249.

Wright, Martin. Justice for Victims and Offenders: A Restorative Response to Crime, 2nd ed. Winchester, England: Waterside Press, 1996: 23-32.

Yamamoto, Eric K. "Friend, or Foe or Something Else: Social Meanings of Redress and Reparations." Denver Journal of International Law and Policy 20 (1991): 223-248.

Yarrow, C.H. Mike. "Quaker Conciliation and Peace Research." Quaker Experiences in International Conciliation. New Haven and London: Yale University Press, 1978.

Yazzi, Robert. "Healing as Justice: the American experience." Justice as Healing, Spring (1995). 
Zehr, Howard. Mediating the Victim-Offender Conflict: The Victim Offender Reconcilation Programme, 4th Ed. Akron, PA: Mennonite Central Committee U.S., 1997.

--. Changing Lenses: A New Focus for Crime and Justice. Scottdale, Pennsylvania and Waterloo, Ontario: Herald Press, 1990.

\section{Methodology}

Bogdan. Robert C. and Sari Knopp Biklen. Qualitative Research for Education. New York: Allyn and Bacon, 1992.

Comstock, Donald E. "A Method for Critical Research." Readings in the Philosophy of Social Science. Eds. Michael Martin and Lee C. McIntyre. MIT Press, 1994.

--.. "A Method for Critical Research: Investigating The World To Change It." Ed. T.R. Young. Transforming Sociology Series of the Red Feather Institute for Advanced Studies in Sociology 72 (1980). 3 Aug. 2001. <http://www.tryoung.com/archives/072comstock.htmll.

Marshall, Catherine and Gretchen B. Rossman. Designing Qualitative Research. Thousand Oaks, CA: Sage, 1995.

McClure, Charles R. and Cynthia L. Lopata. Assessing the Academic Networked Environment: Strategies and Options. Washington, DC: CNI Publications, 1996.

Peterson, George L., Beverly S. Driver, and Robin Gregory. Integrating Economics with other Disciplines. State College, PA: Venture Publishing Inc., 1988.

Wicker, Allan W. "Getting out of our conceptual ruts: Strategies for expanding conceptual frameworks." American Psychologist 40 (1985): 1094-1103. 